\title{
Research Paper \\ The Relationship between Basic Psychological Needs Gratification and Psychological Well-Being in Female Students: The Mediating Role of Self-Efficacy
}

\author{
Somayeh Delforouz ${ }^{1}$, Mohammad Ismail Ebrahimi ${ }^{* 2}$, Malek Mirhashemi ${ }^{3}$, Parvaneh Ghodsi ${ }^{4}$ \\ 1. Ph.D. Student in General Psychology, Central Tehran Branch, Islamic Azad University, Tehran, Iran \\ 2. Assistant Professor, Department of Psychology, Hamedan Branch, Islamic Azad University, Hamedan, Iran \\ 3. Associate Professor, Department of Psychology, Roudehen Branch, Islamic Azad University, Roudehen, Iran \\ 4. Assistant Professor, Department of Psychology, Central Tehran Branch, Islamic Azad University, Tehran, Iran
}

\begin{abstract}
Citation: Delforouz S, Ebrahimi MI, Mirhashemi M, Ghodsi P. The relationship between basic psychological needs gratification and psychological well-being in female students: the mediating role of selfefficacy. J Child Ment Health. 2021; 8 (1):80-96.
\end{abstract}

URL: http://childmentalhealth.ir/article-1-1103-en.html
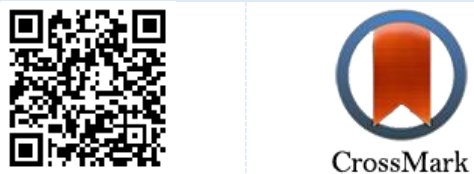

$10.52547 / \mathrm{jcmh} \cdot 8.1 .4$

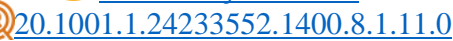

\section{A R T I C L E I N F O}

\section{Keywords:}

Psychological well-

being,

basic psychological

needs,

self-efficacy,

students

Received: 8 Feb 2021

Accepted: 6 Jun 2021

Available: 21 Jun 2021

\section{A B S T R A C T}

Background and Purpose: Considering the importance of students' well-being and the study of variables affecting it, the present study aimed to investigate the mediating effect of self-efficacy on the relationship between basic psychological needs gratification and students' psychological wellbeing.

Method: The method of this research was descriptive-correlational. The statistical population of the study included all female junior high school students in the second district of Hamedan in the academic year 2019-2020 ( $\mathrm{N}=1200)$. The statistical sample of this study was selected using Twostage cluster random sampling method with 302. For data collection, Basic Needs Gratification (Haftlang et.al, 2015), Psychological Well-being (Ryff \& Keyes, 1989) and General Self-efficacy (Sherer and Maddux, 1982) questionnaires were used. The collected data were also analyzed using AMOS structural equations.

Results: The results of data analysis showed that the gratification of basic psychological needs and self-efficacy explain $63 \%$ of the variance of psychological well-being. Gratification of basic psychological needs explains $39 \%$ of the variance in self-efficacy. In addition, self-efficacy has a positive and significant effect on adolescent psychological well-being $(\mathrm{p}<0.001)$ and self-efficacy in the relationship between basic needs and psychological well-being of adolescents has a positive mediating role. And has significance ( $\mathrm{p}<0.001)$.

Conclusion: Based on the findings of this study, it can be concluded that the psychological wellbeing model of adolescents has a good fit based on the gratification of basic psychological needswith self-efficacy mediation. The results of this study also showed that self-efficacy has an important role in satisfying the basic psychological needs and psychological well-being of students; therefore, satisfying the basic needs of students leads to increasing their self-efficacy and ultimately can be very effective in increasing the psychological well-being of students.

* Corresponding author: Mohammad Ismail Ebrahimi, Assistant Professor, Department of Psychology, Hamedan Branch, Islamic Azad University, Hamedan, Iran.

E-mail: Me.ebrahimi@iauh.ac.ir

Tel: (+98) 8134481000

2476-5740/ (C) 2021 The Authors. This is an open access article under the CC BY-NC-ND license

(https://creativecommons.org/licenses/by-nc-nd/4.0/). 


\section{Extended Abstract}

\section{Introduction}

Adolescence is a period of biological, social, and emotional changes. It is also a critical period whose consequences affect a person's whole life (2). The roots of depression, social functioning, self-efficacy feelings, and even suicide ideation lie in adolescence years. One of the possible ways to prevent these disorders is to pay attention to the psychological well-being of adolescents (1). Many factors can predict students' psychological well-being; one is basic needs gratification. Basic psychological needs gratification is a mechanism that leads to balance in all aspects of a person's life (3).

Another factor that is both related to psychological well-being and can mediate the relationship between basic psychological need gratification and psychological well-being, is the self-efficacy variable. Self-efficacy refers to the belief in one's ability to learn and perform at a certain level (6). The relationship between psychological well-being and basic psychological needs gratification has been reported positively in a study by Chang et al. (5). In their research, Borg and Barlow (10) also a positive and significant relationship between self-efficacy and psychological well-being. Also, Eghdami and Yousefi (19) reported a positive relationship between basic psychological needs and academic conflict mediated by self-efficacy. But, the results of a study by $\mathrm{Lu}$ et al. (20) indicated that there is an inverse relationship between basic psychological need gratification and depression symptoms and mental health. Therefore, this study aims to provide a model for predicting adolescents' well-being that can largely predict their psychological well-being.

\section{Method}

The present research was a descriptive correlational study. The statistical population of the present study was all female adolescents in the junior high school in the second district of Hamadan in the academic year 2019-2020, of which 400 were selected as a sample using two-stage cluster sampling. After removing distorted questionnaires and outlier data, in the final analysis, 302 questionnaires were used. The mean and standard deviation of the age of the experimental group was $14.07 \pm 1.54$, and most of the students were in the junior high school second grade. The instruments of the study were: 1 . the Glasser's questionnaire of basic psychological needs (Quoted in 22). It has 35 questions for five basic needs, including the need for survival, belonging, power, freedom, and fun (22); 2. the General self-efficacy questionnaire developed by Sherer and Maddux (25); 3. Ryff and Keyes (28) have developed the well-being questionnaire questionnaire. It has 18 questions and includes six components of self-acceptance, positive relations, autonomy, environmental mastery, purpose in life, and personal growth. It is safe to say that the validated versions of all three questionnaires have been studied and implemented in Iran. Pearson correlation test, confirmatory factor analysis, and structural equation test in the SPSS-26 and the AMOS were used for data analysis.

\section{Results}

Results indicated that the correlation coefficient of psychological well-being and basic psychological needs gratification $(\mathrm{r}=0.51)$ and self-efficacy $(\mathrm{r}=0.65)$ is positive and significant at the level of 0.01 . Mardia's normalized multivariate kurtosis value was used to evaluate multivariate normality. In the present study, it was 4.865 . So, the multivariate normality was confirmed.

According to Fig.1, basic psychological needs gratification and self-efficacy explains $63 \%$ of the variance of psychological well-being. Basic psychological needs gratification explains 39\% of the variance of self-efficacy. 


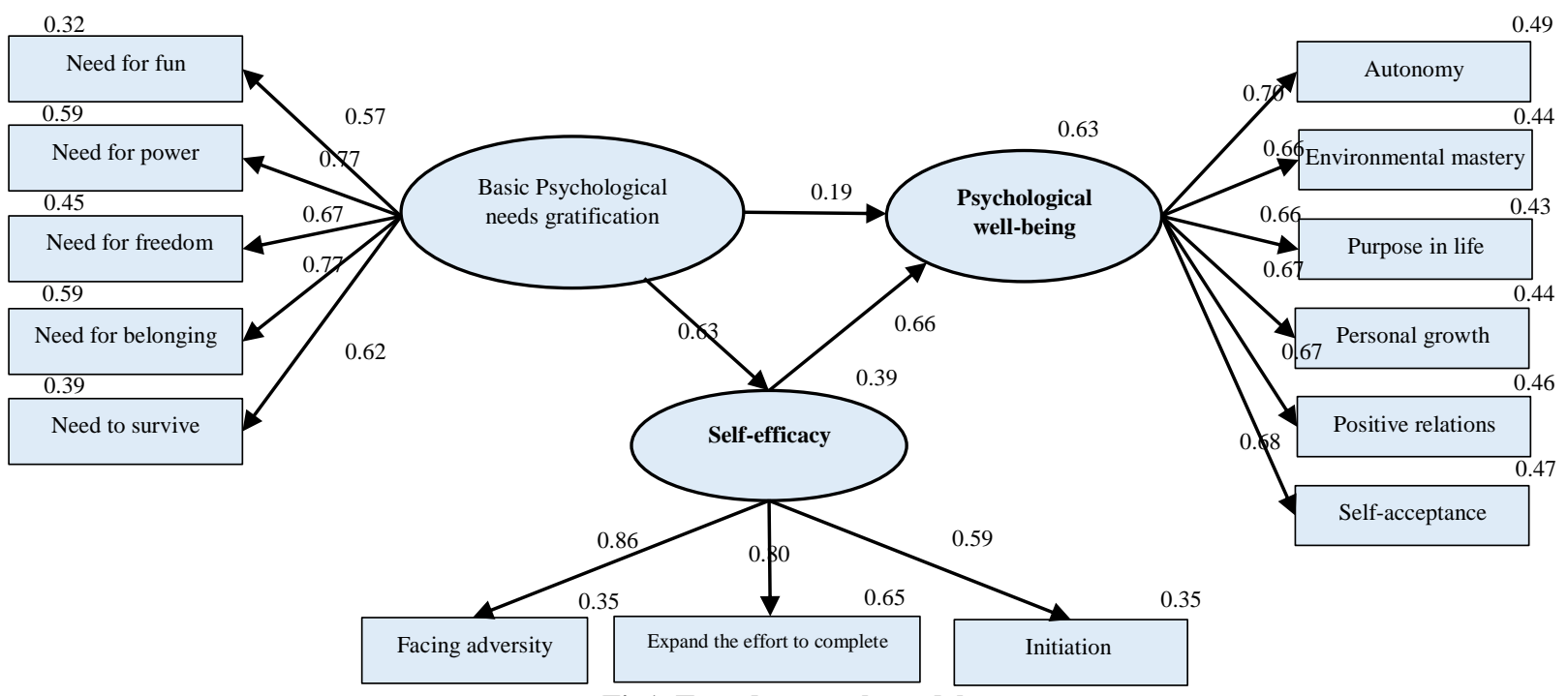

Fig1. Tested research model

Table1. The results of the direct effects

\begin{tabular}{|c|c|c|c|c|c|c|c|}
\hline $\begin{array}{c}\text { Independent } \\
\text { variable }\end{array}$ & $\begin{array}{c}\text { Dependent } \\
\text { variable }\end{array}$ & $\begin{array}{l}\text { Type of } \\
\text { effect }\end{array}$ & $\begin{array}{c}\text { Path } \\
\text { coefficient }\end{array}$ & $\begin{array}{c}\text { Standard } \\
\text { estimation error }\end{array}$ & $\begin{array}{c}\text { t- } \\
\text { statistics }\end{array}$ & $\begin{array}{c}\text { Level of } \\
\text { significance }\end{array}$ & Result \\
\hline $\begin{array}{l}\text { Basic needs } \\
\text { gratification }\end{array}$ & $\begin{array}{c}\text { Psychological } \\
\text { well-being }\end{array}$ & Direct & 0.194 & 0.044 & 2.547 & 0.011 & $\begin{array}{l}\text { Hypothesis } \\
\text { confirmed }\end{array}$ \\
\hline $\begin{array}{l}\text { Basic needs } \\
\text { gratification }\end{array}$ & Self-efficacy & Direct & 0.627 & 0.046 & 6.813 & 0.001 & $\begin{array}{l}\text { Hypothesis } \\
\text { confirmed }\end{array}$ \\
\hline Self-efficacy & $\begin{array}{c}\text { Psychological } \\
\text { well-being }\end{array}$ & Direct & 0.657 & 0.116 & 6.655 & 0.001 & $\begin{array}{l}\text { Hypothesis } \\
\text { confirmed }\end{array}$ \\
\hline
\end{tabular}

According to Table 1, the path coefficient (0.19) and t-statistics (2.547), it is noticeable that at the $95 \%$ confidence level, basic psychological needs gratification has a positive and significant effect on adolescents' psychological well-being. Considering path coefficient (0.63) and t-statistics (6.813), it may be said that at the $99 \%$ confidence level, basic psychological needs gratification has a positive and significant effect on adolescents' self-efficacy. Also, considering path coefficient (0.66) and t-statistics (6.655), it can be stated that at the 99\% confidence level, self-efficacy has a significant and positive effect on adolescents' psychological well-being.

One feature of structural equations is the study of the indirect effects of variables on each other. Table 2 indicates the results of the indirect effects, using the Preacher and Hayes method (31). 
Table 2. Results of the indirect effect of basic needs gratification on adolescents' psychological well-being through self-efficacy

\begin{tabular}{ccccccccc}
\hline Path & Data & Boot & Bias & $\begin{array}{c}\text { Standard } \\
\text { error }\end{array}$ & $\begin{array}{c}\text { z- } \\
\text { statistics }\end{array}$ & $\begin{array}{c}\text { Level of } \\
\text { significance }\end{array}$ & Low limit & High limit \\
\hline $\begin{array}{c}\text { Basic needs gratification } \rightarrow \text { Self- } \\
\text { efficacy } \rightarrow \text { psychological well-being }\end{array}$ & 0.1965 & 0.1965 & 0.0000 & 0.0261 & 7.515 & $<0.001$ & 0.1445 & 0.2569 \\
\hline
\end{tabular}

It can be stated that at the $99 \%$ confidence level, and the number of bootstrap resampling (5000), selfefficacy has a mediating role in the relationship between basic needs gratification and adolescent's psychological well-being, according to table 2 , the indirect path coefficient between basic needs gratification and psychological well-being with mediating role of self-efficacy $(0.1965)$ and Zstatistics (7.515).

\section{Conclusion}

The present study aimed to investigate the mediating effect of self-efficacy in the relationship between basic psychological needs gratification and psychological well-being in female students. The findings indicated that the model of adolescents' psychological well-being based on the basic psychological need gratification with the mediation of the self-efficacy has a good fit. These results are consistent with the findings of Chang et al. (5) that there is a relationship between basic needs gratification and self-efficacy. Also, the results of a study by Borg and Barlow (10) have shown that selfefficacy is associated with personal management and control, psychological well-being, and adolescents' adjustments in the family and it can increase one's psychological well-being. This result also is in line with the results of the studies of Eghdami and Yousefi (19). They confirmed the relationship between basic needs and self-efficacy.

To explain this result, it can be argued that according to the choice theory, the five basic human needs have been emphasized that these needs are innate in all people and are necessary for the wellbeing of individuals. These needs are required for dealing with the environment, developing skills and, growing healthily (4). The basic needs of human beings must be satisfied from an external source, which is the environment. Since psychological wellbeing is a way of adapting to the world, it is believed that basic needs gratification can play a critical role in promoting human relations with their society. Also, it should note that the more attention paid to the basic needs of adolescents, the higher their quality of life, individually and socially, which can have a positive effect on their psychological aspects. Limitations of this study include the dropout of participants and challenges of conducting the study due to the coronavirus diseases-19 (COVID-19) pandemic. We suggest that the present study will be repeating after the end of the pandemic of COVID19 in other age groups with larger sample sizes.

\section{Ethical Considerations}

Compliance with ethical guidelines: This article is extracted from the doctoral dissertation of the first author in the field of general psychology, approved on 2020/05/07 with the ID number: 162290060, in Islamic Azad Unversity, Central Tehran Branch. Also, its executive license was issued by the Organization of Education of the city of Hamadan with letter number 4592 dated 2020/05/30. Other ethical considerations, such as the informed consent of the participants and the principle of privacy policies, and confidentiality of information are also considered.

Funding: This study was conducted without financial support from any organization or institution and is extracted from a doctoral dissertation.

Authors' contribution: The first author was the main designer and ideator of the research and responsible for data collection; the second author was the first supervisor and scientific editor and did the data analysis; the third author was the second supervisor and scientific and literary editor, and the fourth author was the advisor and research controller in this study.

Conflict of interest: There was no conflict of interest for any of the authors.

Acknowledgments: We would like to thank the school officials of Hamedan and the students of these schools who participated in this research. 


\title{
رابطه ارضاى نيازهاى اساسى روانشناختى با بهزيستى روانشناختى در دانش آموزان دختر: نقش ميانجى خود كار آمد يندارى تئى
}

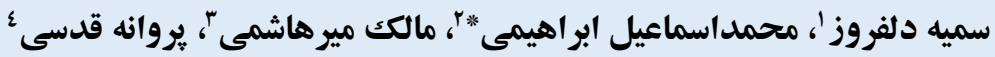

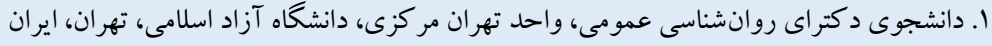

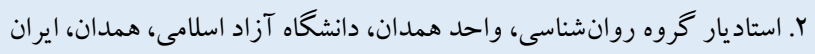

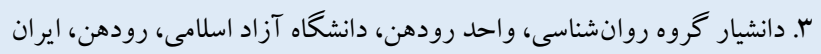

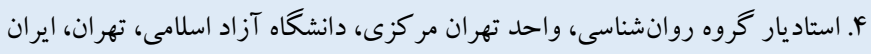

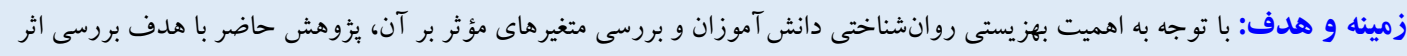

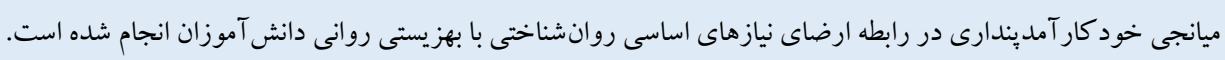

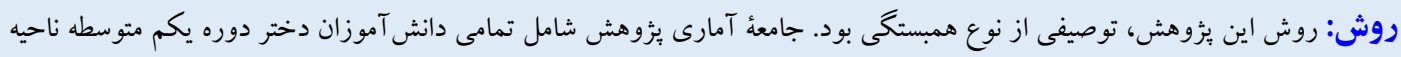

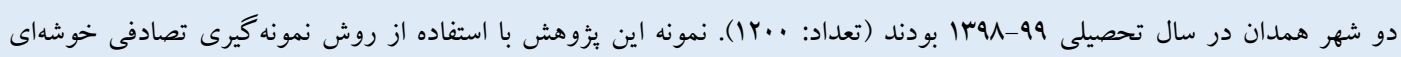

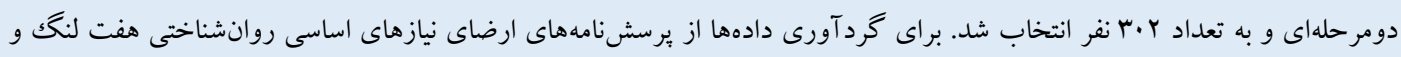
مشخصات مقاله

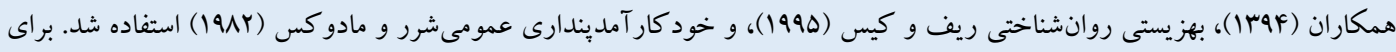
تحليل دادهها از روش معادلات ساختارى با نرمافزار ايموس استفاده شد.

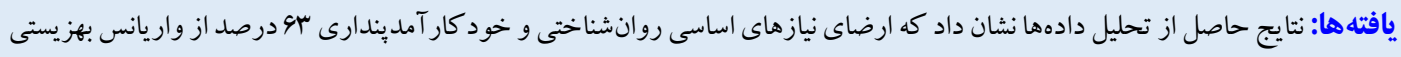

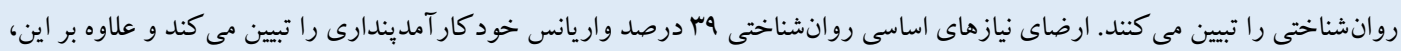

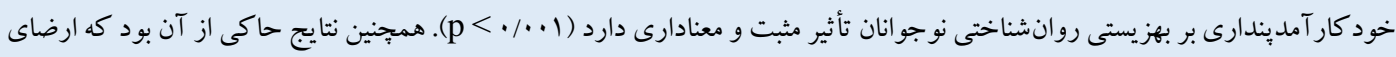

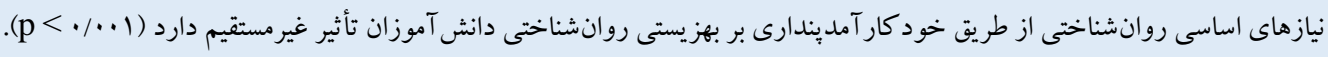

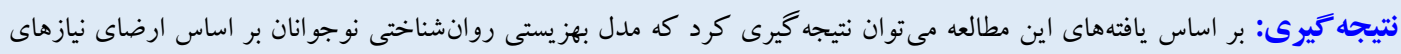

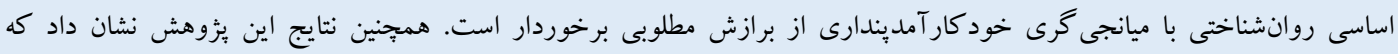

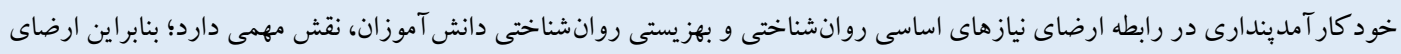

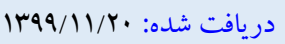

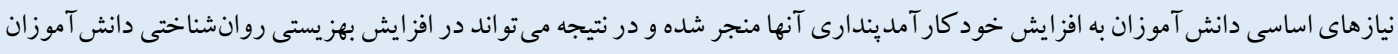


و دامنه هاى مختلف يا موقعيت هاى عملكردى خاصسى داشـته باشـــ. در

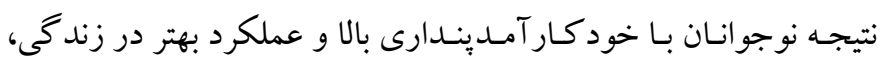

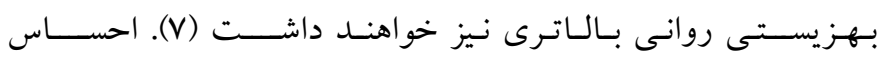

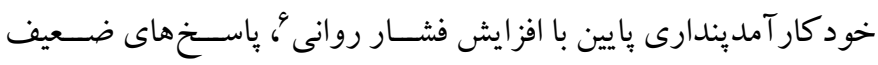

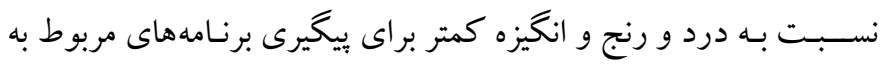

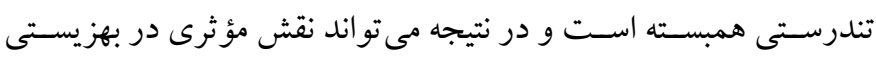

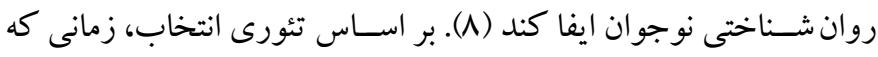

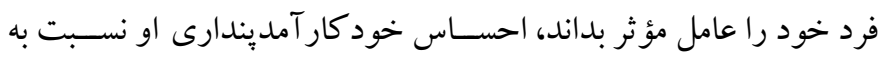

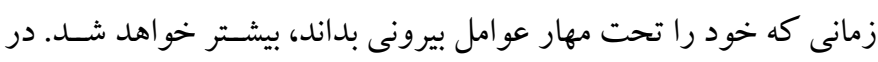

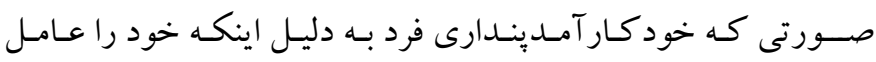

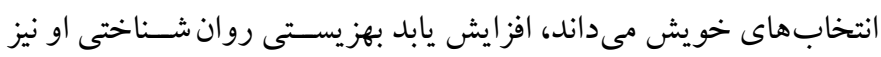

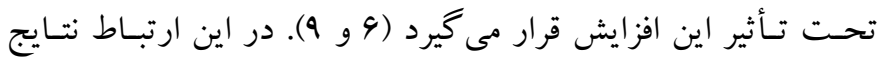

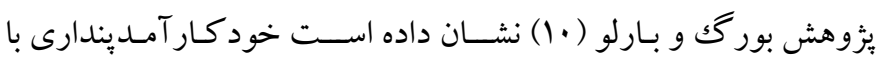

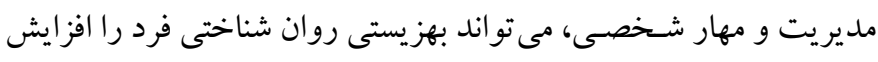

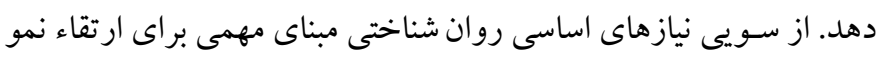

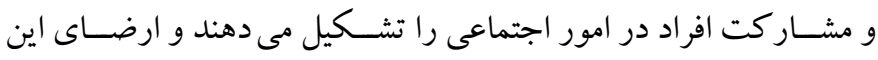

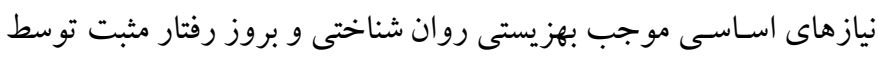

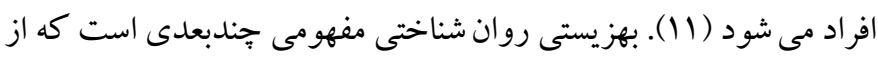

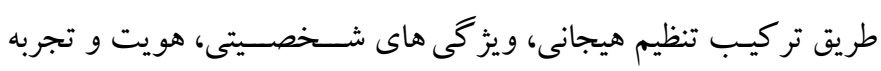

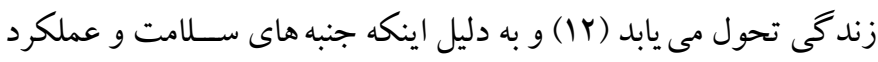

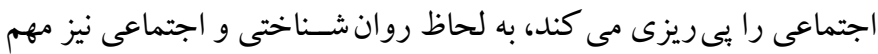

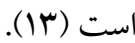

بهزيسـتى روانشـناختى، توانايى مشـاركت فعال در كار و تفريح، ايجاد

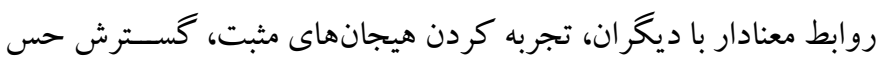

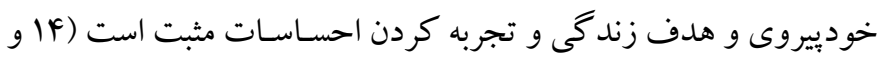

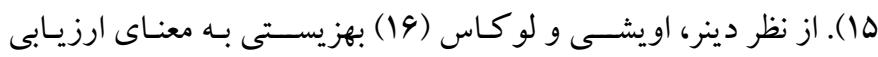

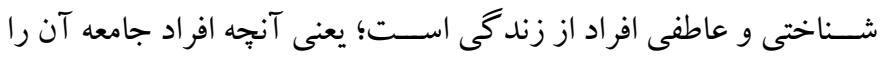

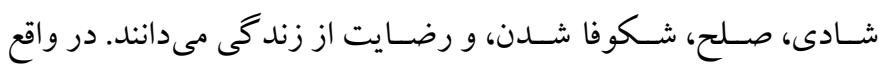

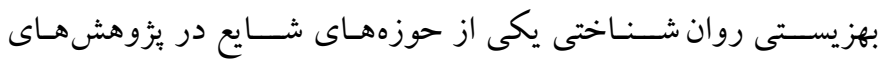

4. Self-efficacy

5. Social cognitive theory

6. Mental pressure مقلdo

در جرخه تحول روانى افراد، بين دوره كودكى و بزركسـالى دوره بسـيار مهم نوجوانى قرار دارد كـه كودكك را از بزر گســال جـدا مى كنـد (1). نوجوانى دوره تغييرات آشـكار شـناختى، زيسـتى، اجتماعى و عاطفى و همجنين دورهاى بحر انى از لحاظ شـناختى، احساسى، جسمانى، و جنسى است كه بيامد آن در طى دوره زندگى و آينده فرد ديده مىشود. اثرات دوران نوجوانى در زندگى و بهزيستى روان شناختى ' افراد و جامعه بسيار قابل توجه اسـت؛ زيرا رفتار بزركسـالان در نوجوانى تثبيت مىشـود و از

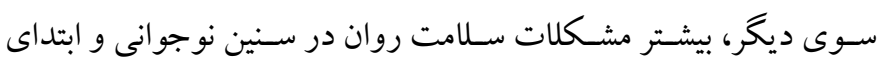
جوانى شكل مى گيرد (Y). در اين سنين است كه بسيارى از نيازهاى افراد آشكار مىشوند و عدم ارضاى آنها مى تواند به افزايش مشكلات سلامت روانى در نوجوانـان منجر شــود. نيـازهـا بـه عنوان خوراكك درونى و

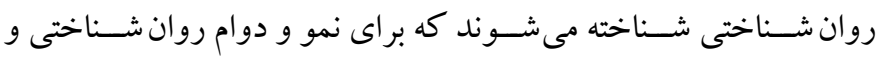
بهزيستى و انسجام ضرورى هستند. ارضاى نيازهاى اساسى روان شناختى مكانيزمى اسـت كه به تعادل در تمامى جوانب زندكى فرد منجر مىشـود (ץ). ارضـاى نيازها را مى توان با توجه به تئورى انتخابَّ مر تبط دانسـت. در يـك تعريف ســاده، موضــوع تئورى انتخـاب در مورد انتخـابـها و

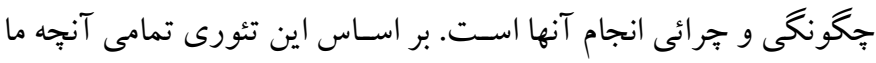
انجام مىدهيم، يكك رفتار اسـت و نيز اينكه همه رفتارها عمدى بوده و از درون ما بر انخيخته مى شـوند (F). بر اين اسـاس ارضـاى نيازهاى اسـاسىى

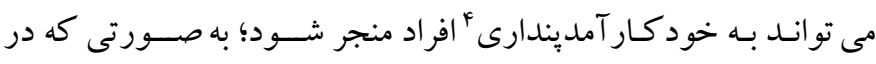
يثزوهش جانگگ، هوانگك و لين (ه) رابطه بين ارضاى نيازهاى اساسى رابا خود كار آمديندارى، مثبت ارزيابى شده است. منظور از خودكـار آمـدينـدارى بـاورهـاى افراد دربـارهُ توانـايى خود دربـاره يـادگيـرى و عـمـلكـرد در ســطح مشــخص اســت (9). خود كار آمد يندارى مفهومى اسـت كه از يكك نظرية كسترده به نام نظرية شـناختى اجتماعى هاسـتخر اج شـده اسـت كه بر طبق آن بيشـرفت آدمى متـأثر از رفتـار خود، شــرايط محيطى، و ويز گىهـاى درونى هميجون

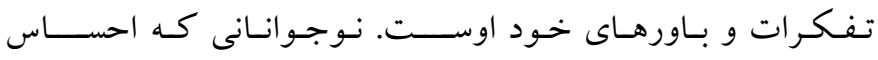
خود كار آمديندارى دارند، مى تواند خودباورى نسبتاً محكمى در حيطهها

1. Psychological well-being

2. Basic psychological needs grafiticaton

3. Choice theory 
مثبـت ارزيـابى كردنـــ. اقـدامى و يوسـفـى ^ (19) نيز رابطهه بين نيازهاى

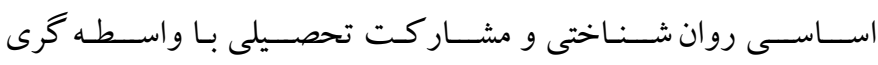
خود كـار آمـدينـدارى را مثبـت كز ارش كردهانـد؛ امـا نتـايج يثزوهش لو، اويسـال و تئو ج (·r) نشـان داد بين ارضاى نيازهاى اساسى روان شناختى با نشانه هاى افسردگى و سلامت روان، رابطه معكوسى وجود دارد. به دليل اهميت نقش خود كار آمديندارى در بهزيستى روانشناختى و تأثيريذيرى كه هر دو متغير از ارضاى نيازهاى اساسى روانشناختى دارند، مى توان خود كار آمديندارى را به عنوان يكك متغير ميانجى بين متغيرهاى بزوهش حاضر قرار داد و از آنجايى كه در هيج يك از يزٔوهشه هاى انجام شده، مدلى جهت بهزيستى روانشناختى بر اساس متغيرهاى ارضاى نيازهاى اساسى با ميانجى گرى خود كار آمديندارى انجام نشده است و همجينين بعضى از يثزوهشها از شيوههاى كذشتهنگ و بعضى از آنها از شيوههاى تئورى انتخاب استفاده كردند، بر اين اساس در اين بثزوهش اين موضوع بررسى شده است كه كدام يكك از اين ديد كاهها در بهزيستى روانشناختى دانش آموزان مؤثر است؟. در نتيجه ضرورى است كه براى بيشبينى بهزيستى نوجوانان، مدلى را ارائه كردتا بتواند تا حدود زيادى ييشبينى كننده بهزيستى روانشناختى آنان باشد؛ بنابراين اين مطالعه با هدف ارائه مدل بهزيستى روانشناختى بر اساس ارضاى نيازهاى اساسى با ميانجى كرى خود كار آمديندارى نوجوانان دختر انجام شده است. مدل مورد نظر و مفروض اين مطالعه به شرح زير است (شكل ().

6. Positive relatedness

7. Positive psychological theory

8. Eghdami \& Yousefi

9. Lu, Uysal \& Teo
روانشـناسى مثبت است و شامل خودييروى'، نمو فردى '، يذيرش خودّا، زندكى هدفمند"، تسلط بر محيطه، و روابط مثبت با ديخر ان واست (IV). در سال هاى اخير گروهى از يزٔوهشخران حوزه سلامت روان با استفاده از

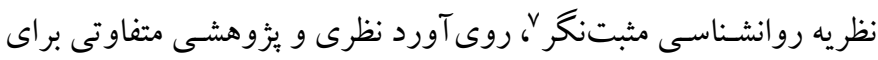
تبيين و مطالعه بهزيسـتى روان شـناختى انتخاب كردهاند. آنان بهزيسـتى روان شناختى را معادل كاركرد مثبت روان شناختى تلقى كرده و آن رادر قالب اصـطلاح بهزيسـتى روانشـناختى مفهومسـازى كردهاند. اين كروه نداشـتن بيمارى را براى احســاس ســلامت كافى نمى دانند، كه معتقدند داشـتن احسـاس رضـايت از زندكى، بيشـرفت، تعامل كار آمد و مؤثر با جهان، انرزى و خلق مثبت، و رابطه مطلوب با جمع و اجتماع و بيشــرفت مثبت از مشخصه هاى فرد سالم است (F). به دليل اهميت دوران نوجوانى، توجه به بهزيستى روان شناختى در اين سنين همواره يكى از مسائل مورد

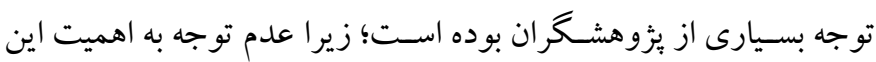
موضـوع مى تواند مشـكلات جبر ان نايذيرى را براى فرد و جامعه به وجود آورد. هدف روانشـناسـى مثبت نيز افزايش احســاسـات مثبت از طريق افزايش شــادى، تعامل در زندكى، و بهزيسـتى روان شــاختى اسـت كه مى تواند كيفيت زندكى دانش آموزان را ارتقا بخشـد (1N). بر اين اسـاس رابطه بين بهزيسـتى روانى با ارضـاى نيازهاى اسـاسـى روانشــاختى در

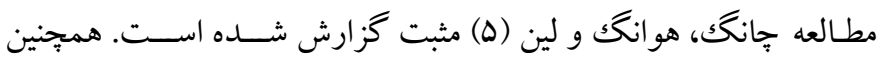
بورگك و بارلو ( • (1) رابطه خود كار آمديندارى با بهزيستى روانشناختى را 


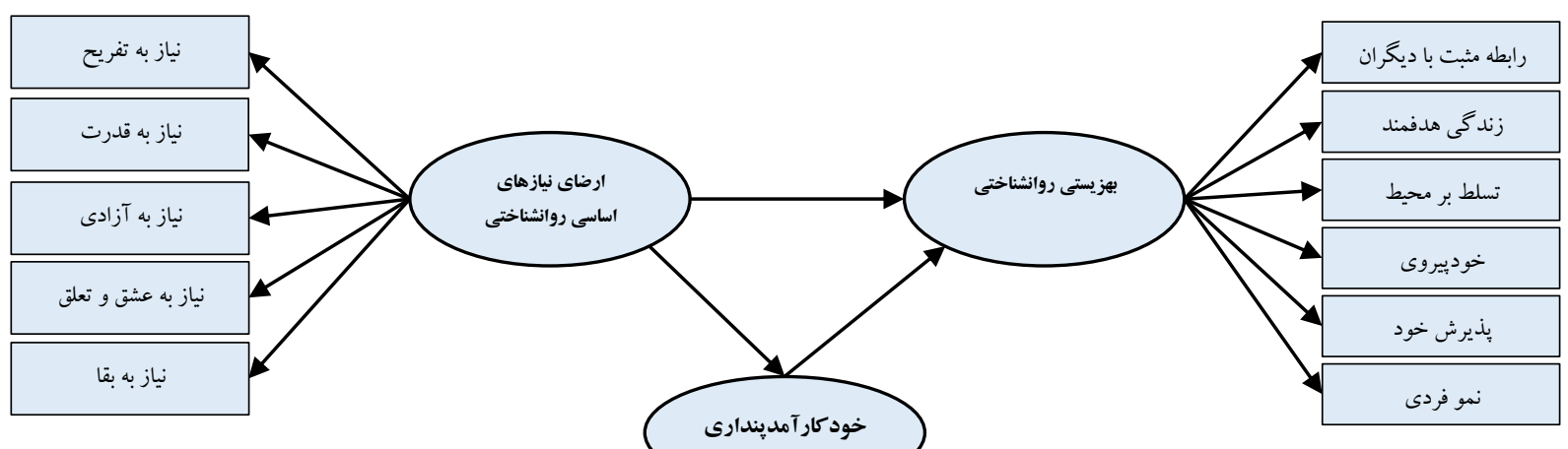

خود كار آمديندارى

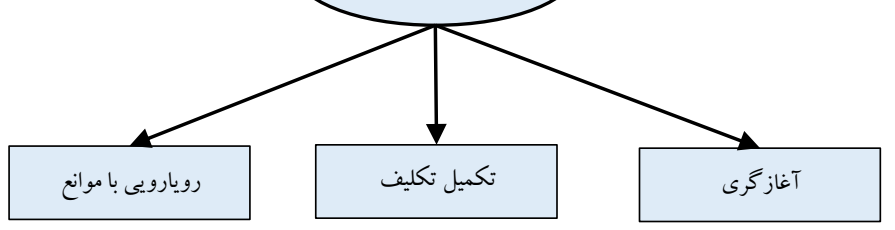

شكل ا: مدل عملياتى بثوهش

تيزهوشى قرار نداشـتند) و رضـايت كامل والدين بوده اسـت. همجنين

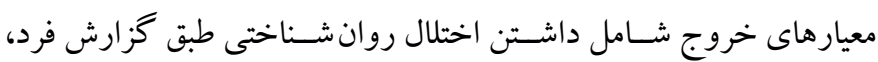

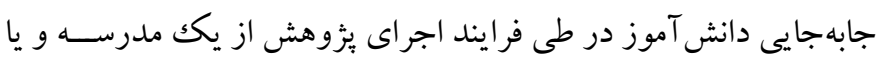

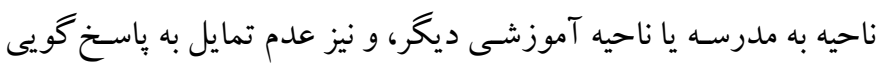

به كويه است است.

ب) (بزار

1. برسش نامه /رضاى نيازهاى اساسى روانشناختى': برسش نامه نيازهاى

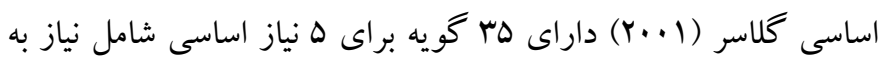

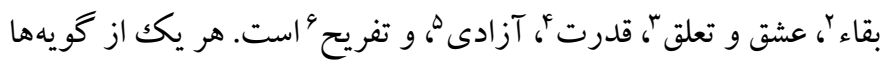

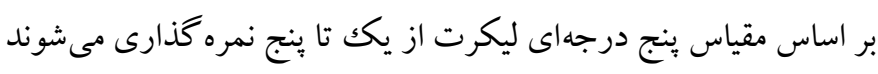

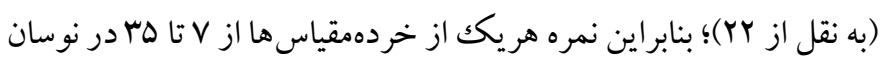

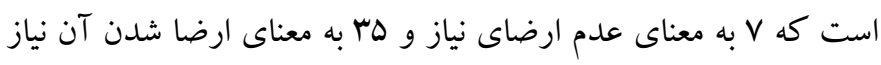

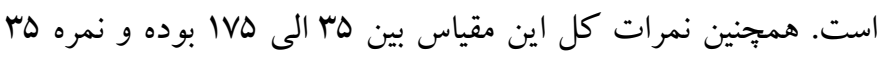

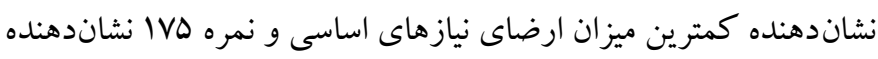

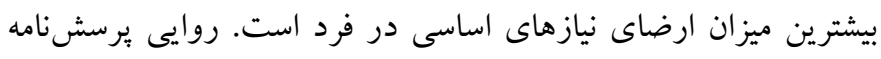

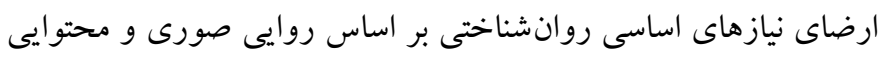

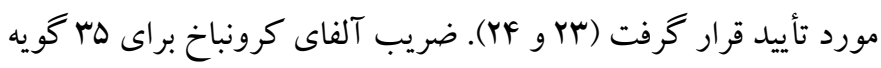

\footnotetext{
4. Power

5. Freedom

6 . Fun
}

الف) طرح يخزوهش و شــركت كنند كان: يثزوهش حاضــر، مطالعهاى توصـيفى از نوع همبسـتخى با اسـتفاده از روش الخوى على يا معادلات

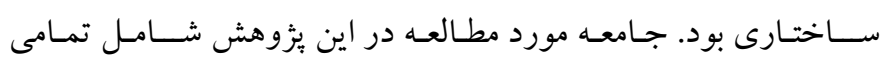
دانش آموزان دختر دوره يكم متوســهه ناحيه دو شــهر همدان در ســال

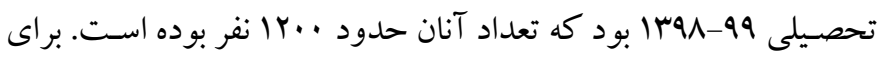
بر آورد حجم نمونه در اين يزووهش بر اسـاس بيشـنهاد وسـتلند (Y) عمل شـده اسـت كه به منظور نمونه گيرى در روش معادلات ساختارى براى هر

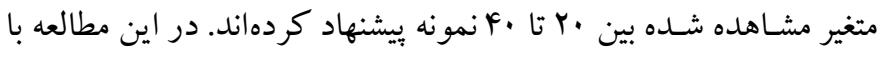

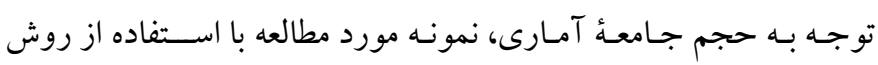
نمونه گيرى خوشـهاى دومرحلهاى انتخاب شـــ. حجم نمونه جهت حفظ شر ايط نمونه مناسب براى معادلات ساختارى تعداد ..F نفر تعيين شد كه در نهايت ץ.r برسـش نامه جهت تحليل نهايى مورد اسـتفاده قرار گرفت (بـه علـت نقص در تكميـل برســش نـامسه و نيز حذف نمونه هاى برت).

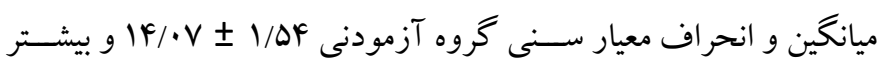
آنها، دانش آموزان كلاس هشتم بودند. ملاككهاى ورود به يزو هش شامل برخوراردى از دامنـه هوشــى متوســط (در دامنـه كمتوانى ذهنى و يـا

1. Basic Needs grafiticaton in General Scale

2. Survival

3. Belonging 


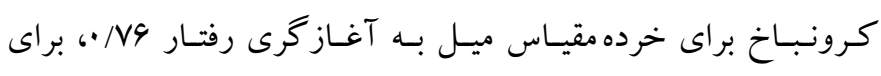

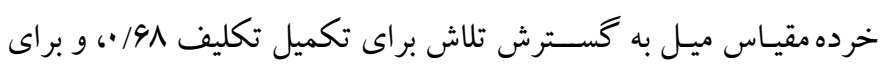

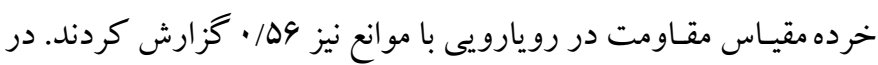

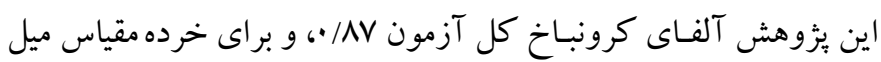

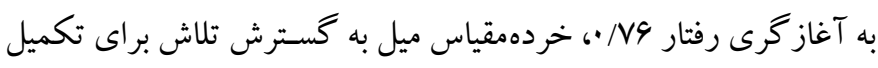
تكليف NV •، و براى خرده مقياس مقاومت در رويارويى با موانع نيز برابر

م بو/ • به دست آمد.

r. برسـش نامه بهزيستى روانشسناختى ريف و كيس ه: اين ابزار در سـال

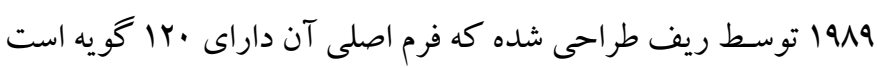

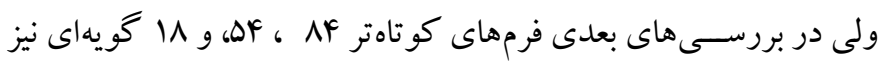

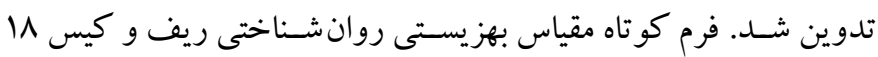

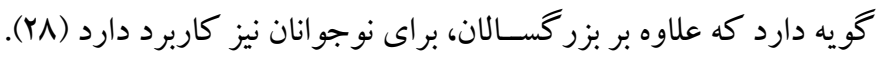

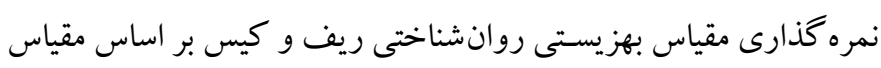
شـش درجـه اى ليكرت از يكك (كاملاً مخالفم) تا شــش (كاملاً مو افقم)

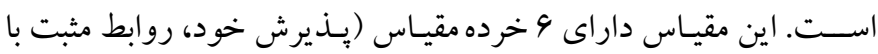
ديخر ان، خودييروى، تسلط بر محيط، زندگى هدفمند، و نمو فردى) بودهـ

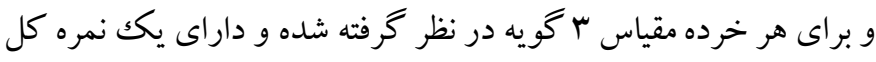

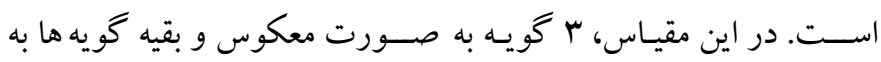

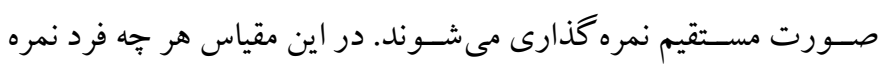

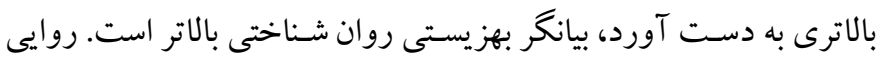
مقياس بر اسـاس شـاخصهاى روايى صسورى و محتو ايى مورد تأييد قرار

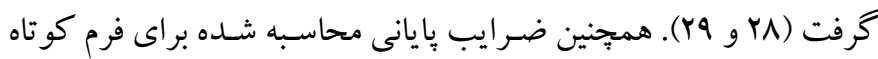

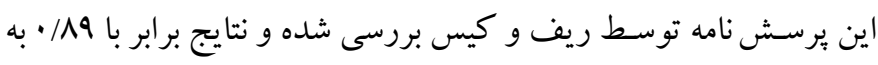

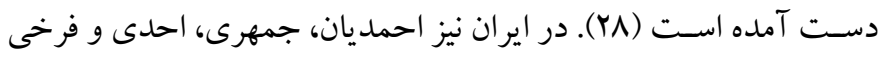

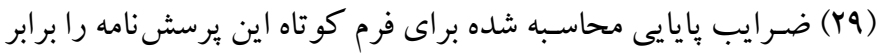

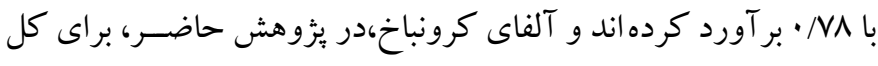

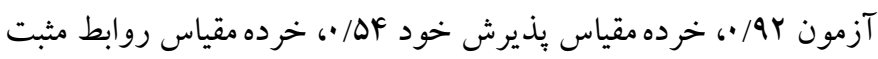

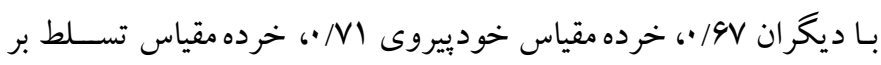

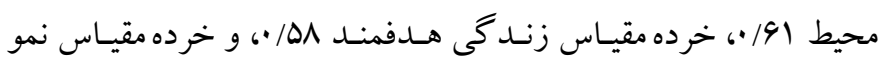

$$
\text { فردى 194 • به دست آمده است. }
$$

4. Persistence in the face of adversity

5. Psychological Well-Being Ryff

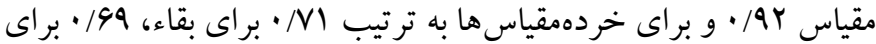

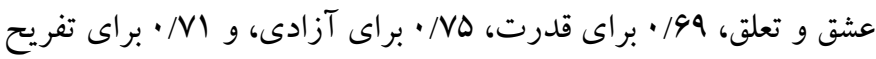

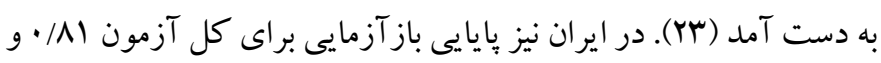

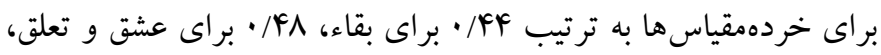

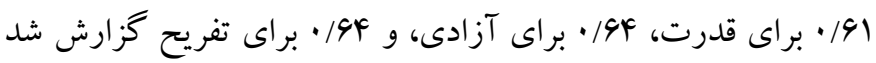

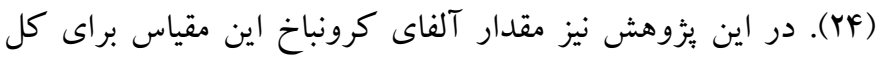

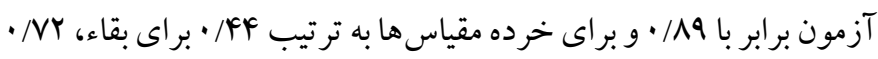

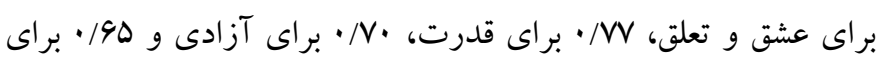
تفريح به دست آمد.

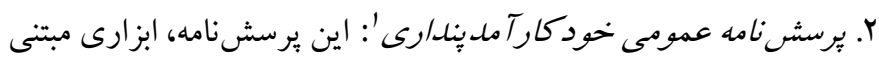

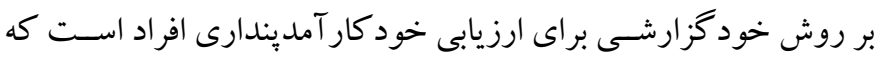

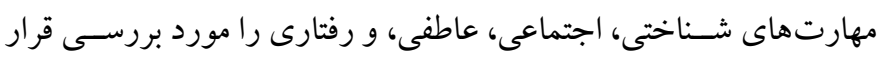

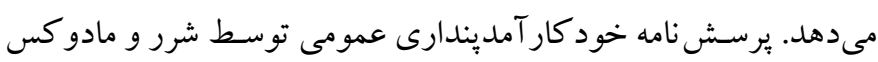

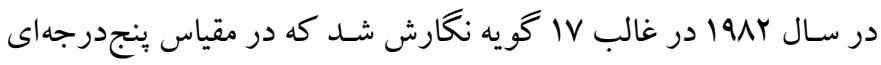

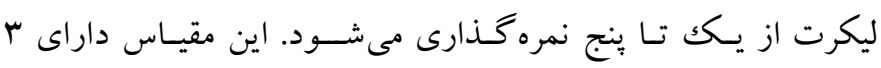

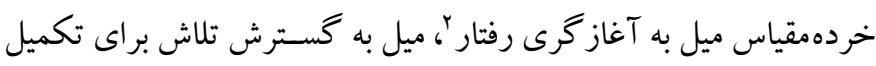

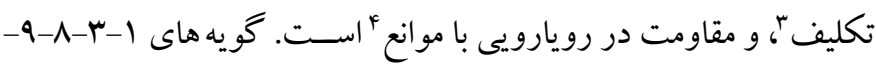

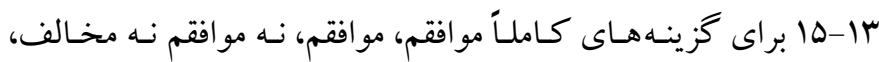

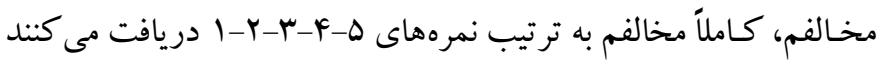

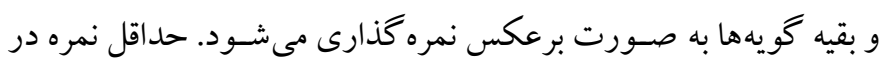

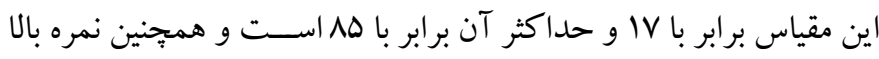

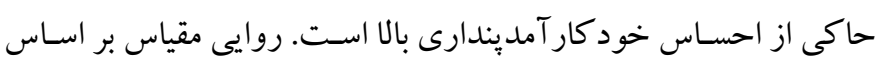

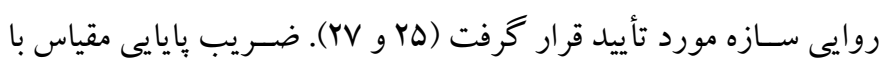

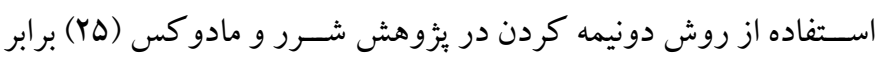

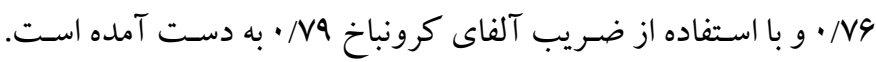

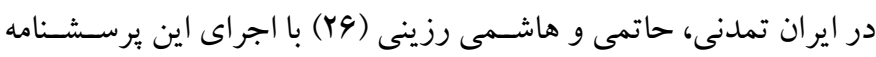

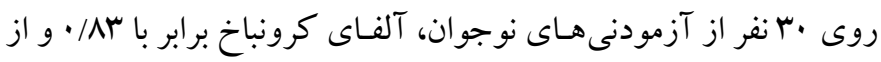

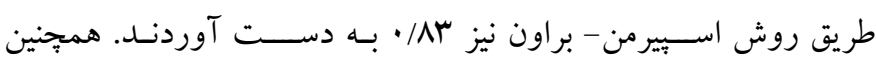
اصسغرنزاد، احمدى ده قطب الدينى، ولى الله و خدايناهى (YV) نيز مقدار

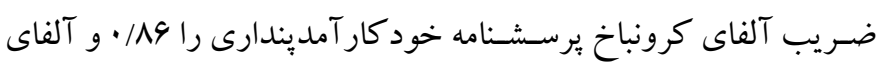

1. General Self - Efficacy Inventory (Gses)

2. Willingness to initiate behavior

3. Willingness to expand effort in completing the behavior 
باز گردانده شـده كه يس از بررسى يرسشنامه ها و حذف يرسش نامه هاى مخـدوش يـا نـاقص، در نهايست تعداد ب بس يرسـش نامه مورد تأييد قرار كرفت. در مرحله بررسـى مدل نيز از اين تعداد، بr يرسـش نامه حذف شده و بنابر اين Y.r برسش نامه در تحليل نهايى مورد استفاده قرار كرفت. براى تحليل اطلاعات در اين يزوهش از شـاخصهاى توصـيفى ميانخين، انحر اف معيار، و كمينه و بيشينه و در سطح استنباطى از ضريب همبستخى بيرسـون، تحليل عاملى تأييدى، و معادلات ساختارى با نسخه وب نرم افزار SPSS

\section{يافتهها}

در جدول اشهـاخص هاى توصـيفى متغيرهاى بثزوهش شــامل ميانگين،

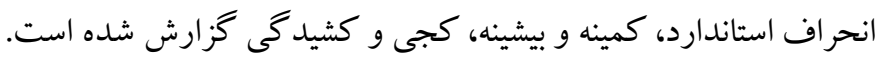

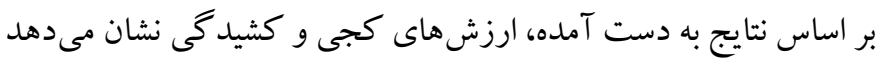

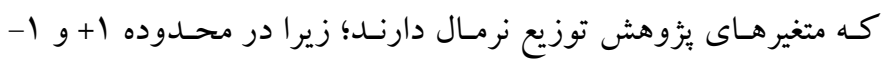

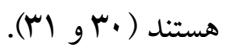

ج) روش اجرا: بهمنظور جمع آورى اطلاعات به روش ميدانى، آزمونخر

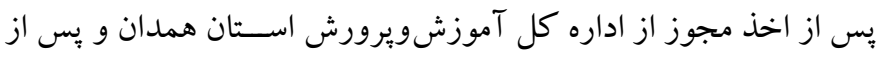

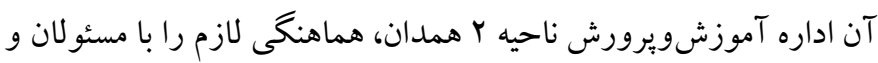

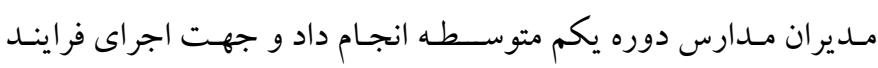

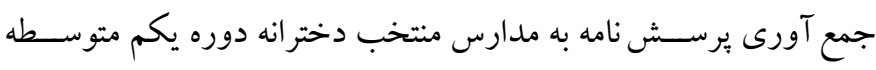

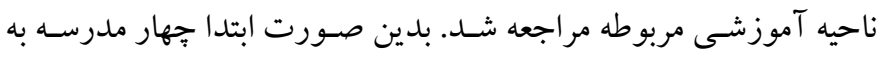

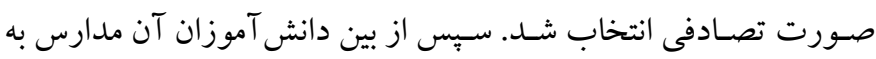

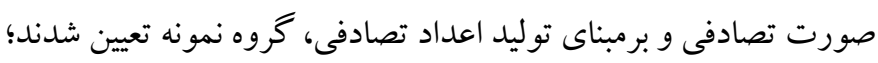

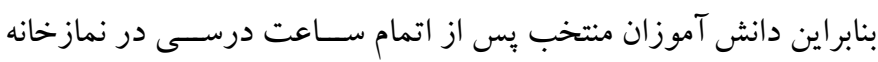

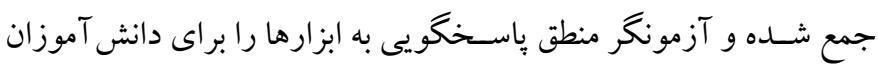

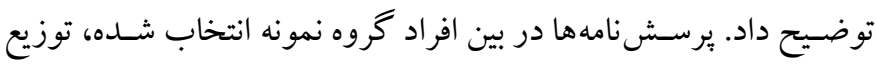

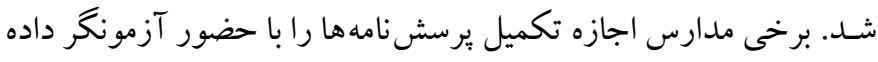

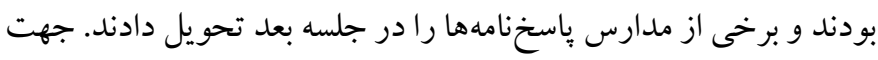

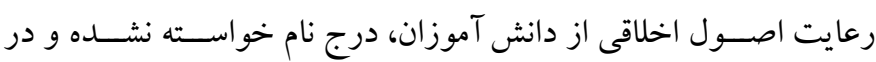

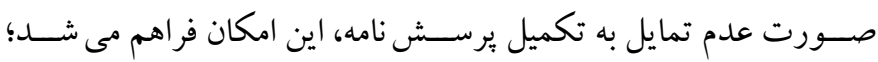

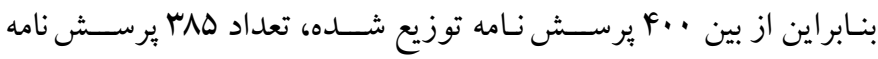

جدول ا: آمار توصيفى متغيرهاى يثوهش

\begin{tabular}{|c|c|c|c|c|c|c|}
\hline كشيدكى & كجى & بيشينه & كمينه & انحراف معيار & ميانكين & معيار \\
\hline$-\cdot /$ Fq &.$/ .99$ & $1 \cdot 1$ & kr & $11 / 1$. & $91 / 99$ & بهزيستى روانشناختى \\
\hline$\cdot / \cdot \wedge \Delta$ & $-\cdot / 491$ & $\Lambda \Delta$ & r & 1.110 & $99 / \mu \wedge$ & خو دكار آمديندارى \\
\hline$\cdot / 490$ & $-\cdot / \cdot \wedge r$ & IVD & vi & $10 / 90$ & $1 Y 9 / 90$ & ارضاى نيازهاى اساسى \\
\hline
\end{tabular}

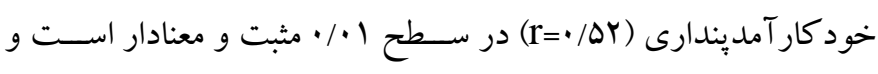
ضـريب همبســتِى ارضــاى نيازهاى اســاسـى و خود كار آمديندارى

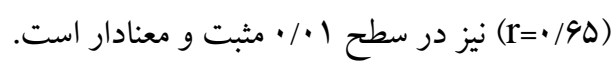

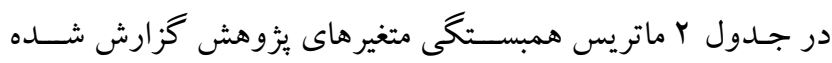
اســت. همان طور كه مشــاهده مى شـود ضــريب همبسـتخى بهزيسـتى

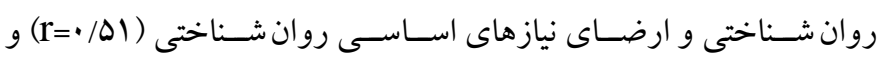

جدول r: همبستغى متغير هاى بثزوهش

\begin{tabular}{|c|c|c|c|}
\hline خود كار آمديندارى & بهزيستى روانشناختى & ارضاى نيازهاى اساسى روانشناختى & معيار \\
\hline & & 1 & ارضاى نيازهاى اساسى روانشناختى \\
\hline & 1 & $\cdot / 0 \cdot 9^{* * *}$ & بـ بهزيسى روانشناختى \\
\hline 1 &.$/ 949 *$ & $\cdot / \Delta r^{* * * *}$ & خو دكار آمديندارى \\
\hline
\end{tabular}

روش، للزم اسـت كه نرمال بودن جندمتغيره بررسى شود. در اين يزوهش براى بررسى نرمال بودن جندمتغيره از ضـريب كشيدكى استاندارد شده
جهــت آزمون الكُوى نظرى يُزوهش و برازش آن بـا دادههـاى كرد آورى شـده از روش بيشينه احتمال استفاده شد. جهت استفاده از اين 
ريشـه ميانخين مربعات باقيمانده اسـتاندارد شــده به عنوان شــاخص هاى برازش مطلق، شـاخص برازش تطبيقىه، شـاخص برازش هنجار شـده و شــاخص برازش هنجار نشــده لبه عنوان شــاخص هاى برازش تطبيقى و مجذور خى بر درجه آزادى، شــاخص برازش ايجازٌ و مجذور ميانگين مربعـات خطـاى تقريسب · بر اى شــاخص هاى برازش تعديل يافته در نظر كرفته شدهاند.
مرديا' استفاده شد كه در يزوهش حاضر F/AD به دست آمد؛ بنابر اين به دليـل كمتر بودن اين مقدار از مقدار مفروض ه، مىتوان نتيجه كرفت كه نرمال بودن جندمتغيره مورد تأييد قرار كرفت.

در جدول ب مشتصسه هاى برازندكى الكوى معادلات ساختارى يعنى برازش مطلق، تطبيقى و تعديل يافته به تفكيك گز ارش شده است. در اين يزووهش شـاخص نيكويى برازش بَ، شاخص نيكويى برازش تعديل يافته

جدول rا: شاخصهاى نيكويى برازش الكوى آزمون شده يزوهش

\begin{tabular}{|c|c|c|c|}
\hline \multicolumn{4}{|c|}{ شاخصهاى برازش مطلق } \\
\hline SRMR & AGFI & GFI & 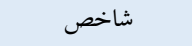 \\
\hline$\%$. &.$/ 94 T$ &.$/ 94$ & مقدار به دست آمده \\
\hline كمتر از هـ/• & بيشتر از •A/· & بيشتر از •9/• & حد قابل يذيرش \\
\hline NNFI & NFI & CFI & شاخص \\
\hline$\cdot / 91 \Delta$ & $\cdot / 94 \Delta$ &.$/ 941$ & مقدار به دست آمده \\
\hline بيشتر از •9/· & بيشتر از •9/· & بيشتر از •9/. & حد قابل يذيرش \\
\hline \multicolumn{4}{|c|}{ شاخصهاى برازش تعديليافته } \\
\hline RMSEA & PNFI & $\chi^{r} / \mathrm{df}$ & شاخص \\
\hline$\cdot / \cdot r q$ & $\cdot /$ V9N & $1 / 49$ & مقدار به دست آمده \\
\hline كمتر از ^••• & بيشتر از •19. & كمتر از ب إ & حد قابل پذيرش \\
\hline
\end{tabular}

آزمون شده بر اى فرضيه هاى بثوهش همر اه با مقادير استاندارد شده روى هر كدام از مسـيرها درج شـده اسـت. همان طور كه مشاهده مىشود تأثير ارضـاى نيازهاى اسـاسى بر خود كار آمديندارى و بهزيستى روان شناختى

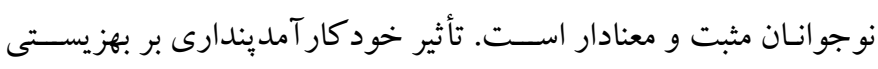
روانشناختى نوجوانان نيز مثبت و معنادار است.

6. Normalized Fit Index

7. Unnormal Fit Index

8. Chi Square on The Degree of Freedom (X2/Df)

9. Shortness Fit Index

10. Squared the Mean Squares of the Approximation Error (RMSEA)
در جـدول ب مقادير به دســت آمده در يزوهش حاضــر و حد قابل

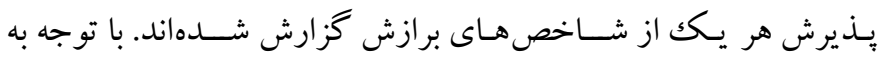
ديد كاه هوير، كو كلان و مولن (Yr) نتايج به دست آمده نشان مىدهد كه شـاخص هاى برازش مدل، همخى در سطح مناسبى هستند و داده هاى اين يثزوهش با سـاختار عاملى اين مدل، برازش مناسبى دارد. در شكل ب مدل
1. Mardia's normalized multivariate kurtosis value

2. Fit Goodness Index

3. Adjusted Fit Goodness Index

4. Root Mean Square Residual

5. Adaptive Fit Index 


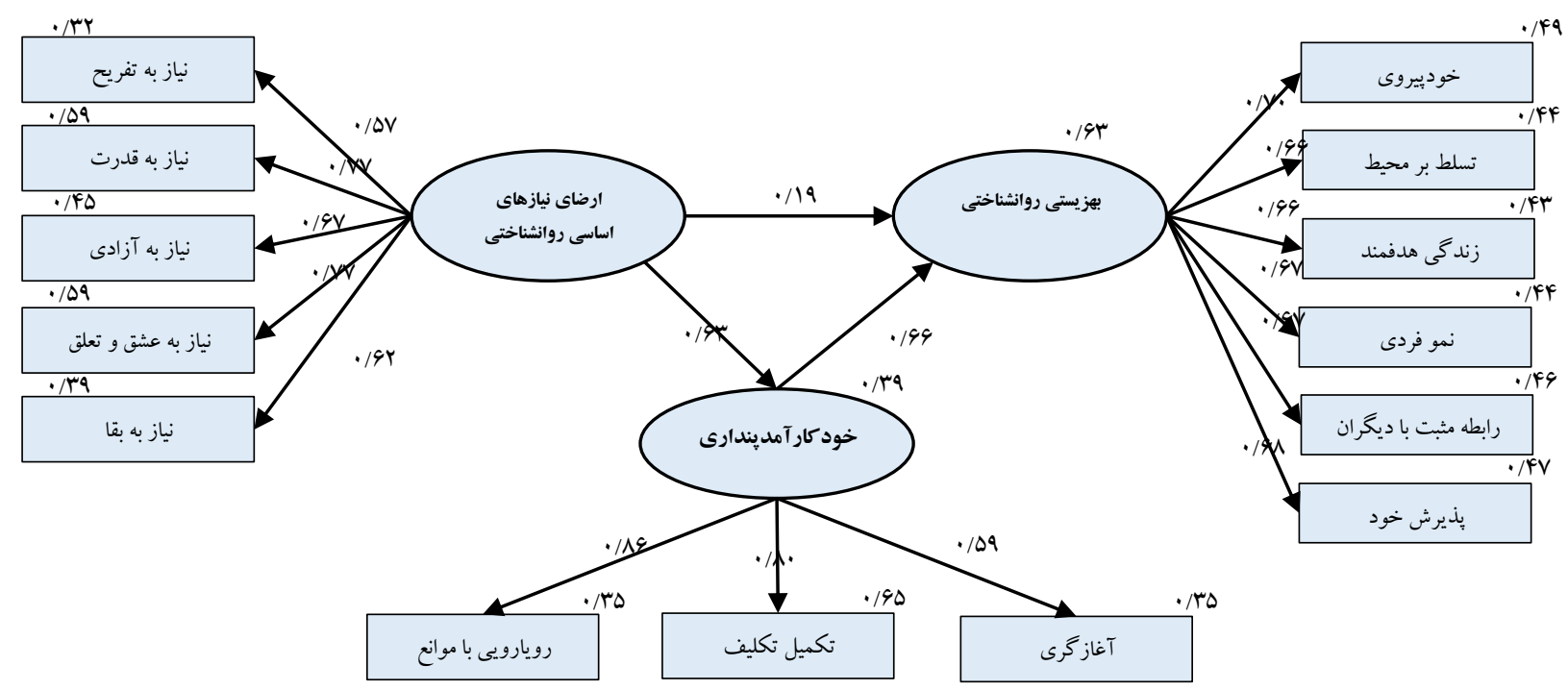

شكل r: الكوى آزمون شده يزوهش

خود كار آمديندارى را تبين مى كند. در جدول \& اثرات مسـتقيم، آماره t و سطح معنادارى مسيرهاى مورد نظر يزوهش كزارش شده است.
بـا توجه به شــكل ب ارضــاى نيازهاى اســاسـى روان شـــاختى و خود كار آمد يندارى سو درصـد واريانس بهزيستى روان شناختى، همجِنين

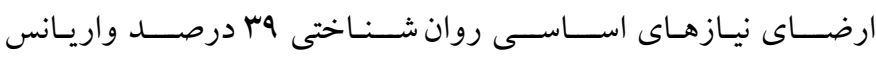

جدول ع: نتايج مربوط به اثرات مستقيم

\begin{tabular}{|c|c|c|c|c|c|c|}
\hline نتيجه & سطح معنادارى & نسبت بحرانى & خطاى معيار & ضر ايب استاندارد & 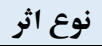 & 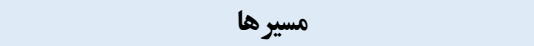 \\
\hline تأييد فرضيه &.$/ 11$ & Y/DFV &.$/ \cdot \mu q$ &.$/ 194$ & مستقيم & ارضاى نيازهاى اساسى ـ بهزيستى روانشناختى \\
\hline ت تأييد فرضيه & $<\cdot / \cdot \cdot$ & G/AIr &.$/ .49$ &.$/ 9 Y V$ & مستقيم & ارضاى نيازهاى اساسى ـ خود كار آمديندارى \\
\hline تأييد فرضيه & $<\cdot / \cdot \cdot 1$ & $9 / 900$ &.$/ 119$ & $.190 \mathrm{~V}$ & مستقيم & خود كار آمديندارى ـ بهزيستى روانشناختى \\
\hline
\end{tabular}

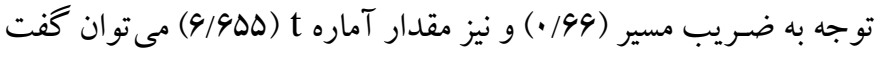
در ســـح اطمينـان 99 درصـــد، خود كـار آمـدينــارى بر بهزيســتى روانشناختى نوجوانان تأثير مثبت و معنادارى دارد.

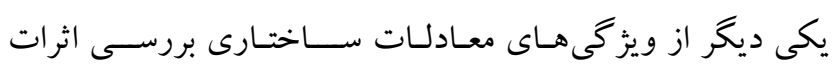
غير مستقيم متغيرها بر يكديخر است. در جدول ه نتايج اثرات غيرمستقيم به روش يريجير و هايز (سM) ارائه شده است.
همان كونه كه در جدول F مشـاهده مى شـود با توجه به ضريب مسير

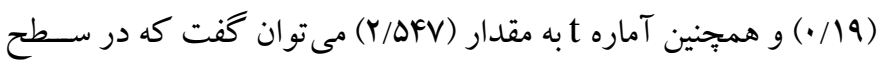
اطمينان ه9 درصـد، ارضـاى نيازهاى اسـاسـى روانشـناختى بر بهزيسـى روانشـاختى نوجوانان تأثير مثبت و معنادارى دارد. با توجه به ضــريب

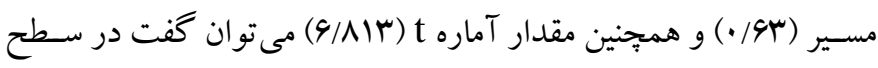
اطمينـان 99 درصــــ، ارضــاى نيـازهـاى اســاســى روان شـــــاختى بر خود كـار آمـدينـدارى نوجوانـان تـأثير مثبت و معنادارى دارد. همجنين با يا

جدول 0: نتايج مربوط به اثر غير مستقيم ارضاى نيازهاى اساسى بر بهزيستى روانشناختى نوجوانان از طريق خود كار آمديندارى

\begin{tabular}{|c|c|c|c|c|c|c|c|c|}
\hline حدبالا & حديايين & سطح معنادارى & T & خطاى استاندارد & سو كيرى & بوت & داده & مسير \\
\hline$\cdot / r \Delta 9 Q$ & - IFFA & $<\cdot / \cdot \cdot 1$ & $V / \Delta / Q$ & $\cdot / \cdot r 91$ & $\cdot / \cdots$ &.$/ 1990$ &.$/ 1990$ & 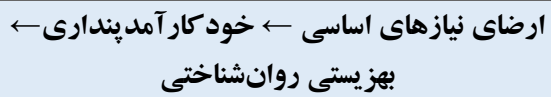 \\
\hline
\end{tabular}


بنيـادى بـه عنوان انرزى لـازم براى مشــاركـت فعـال بـا محيط، برورش

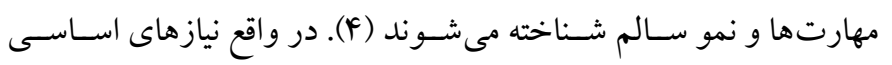

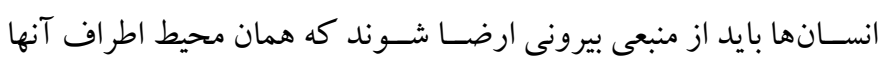

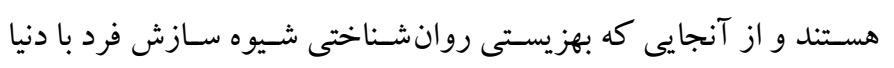

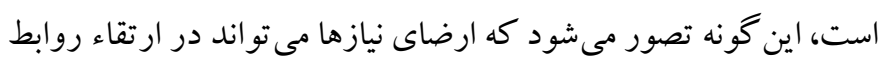

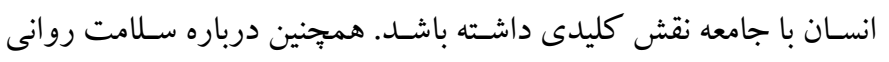

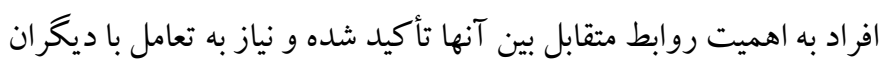

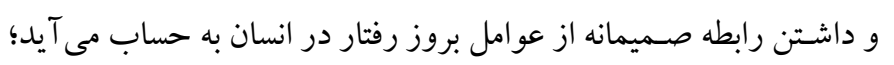

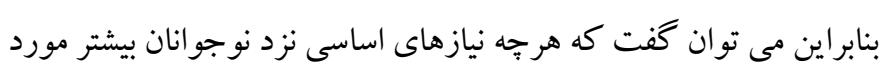

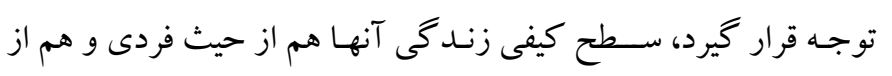

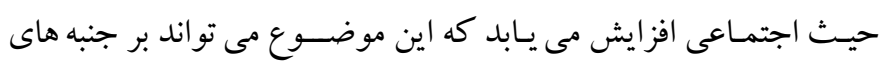

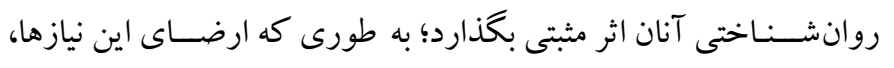

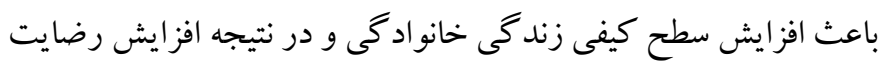

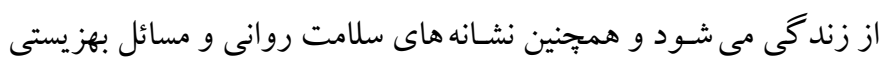

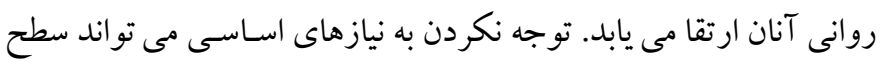

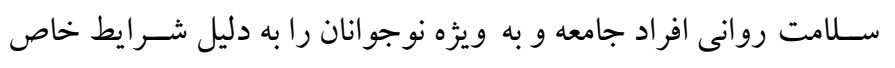

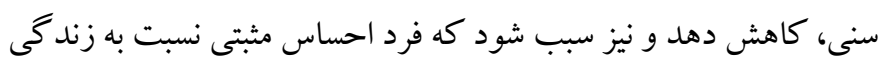

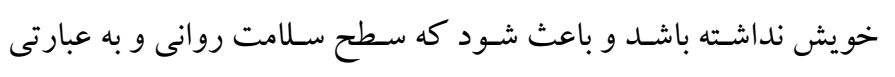

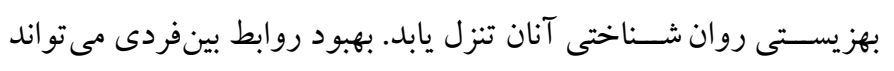

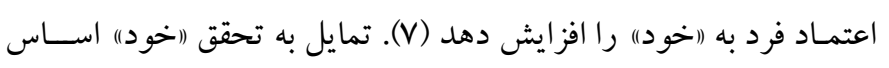
تمام رفتارهاى انسـان بوده و تمامى رفتارهاى انسـان به وسـيله اين تمايل

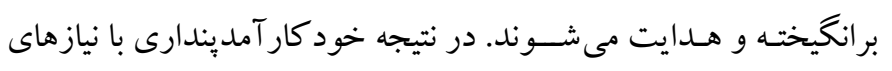

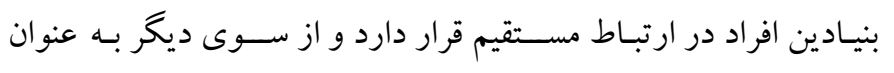

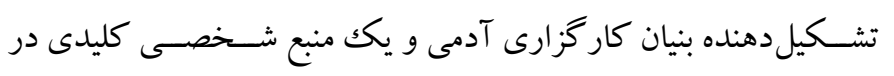

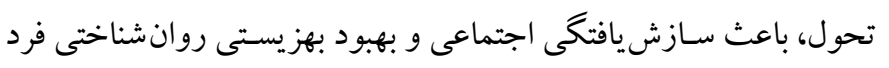

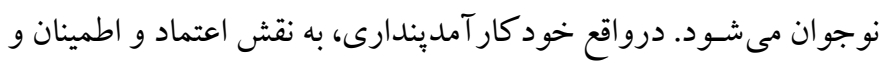

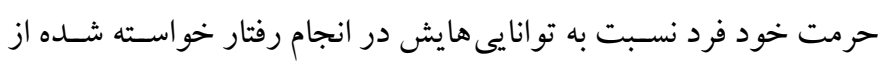

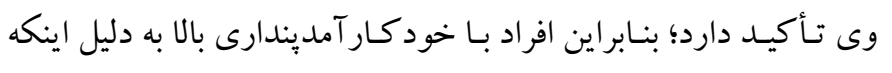

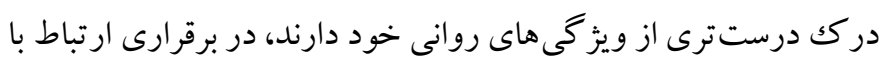

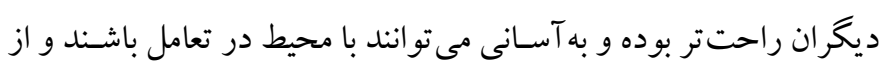

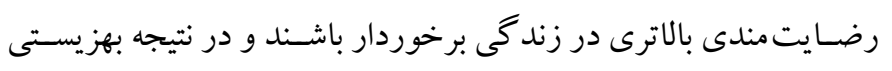
روانشناختى بهترى را تجربه كنند.
همان گونه كه در جدول ه مشاهده مى شود، ضريب مسير غيرمستقيم

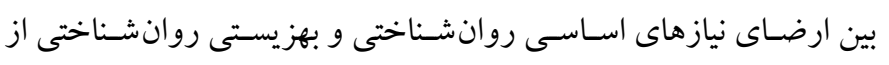

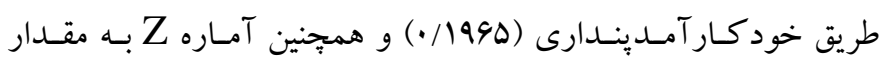

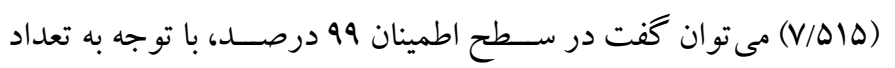

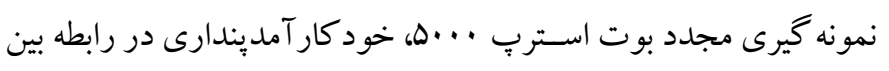

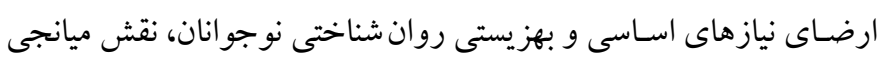
دارد.

\section{بحث و نتيجه كيرى}

هدف اين يُوهش بروستى نقش ميانجى خود كار آمديندارى در رابطه با

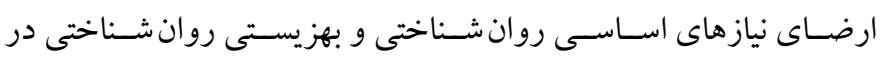

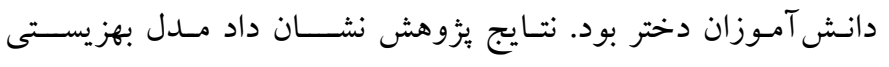

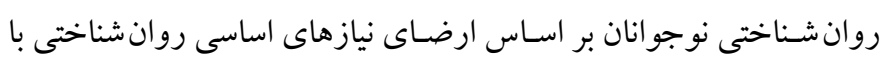

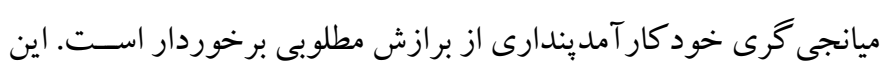

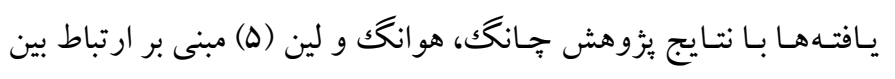

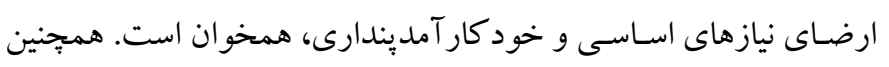

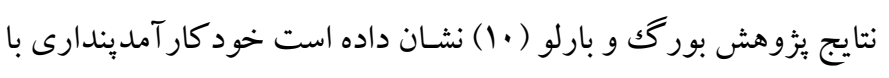

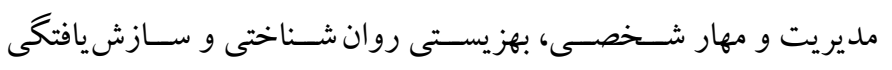

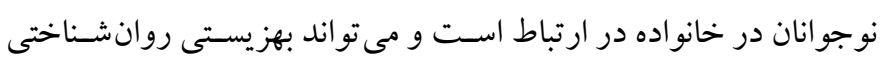

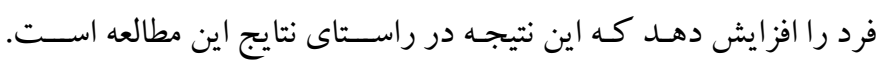
همجنين نتايج مطالعات اقدامى و يوسـى (19) مبنى بر رابطه بين نيازهاى

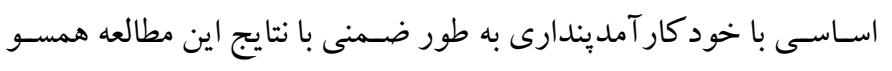

\section{هستند.} همجينين نتايج يزٔوهش لو، اويسال و تئو (·Y) نشـان داد بين ارضساى

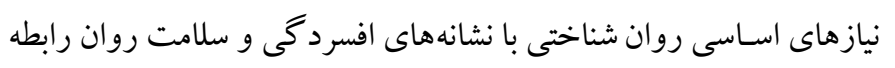

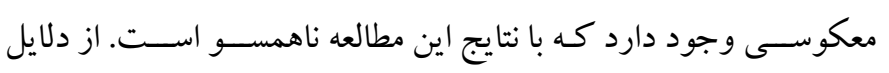

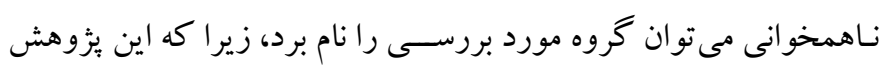

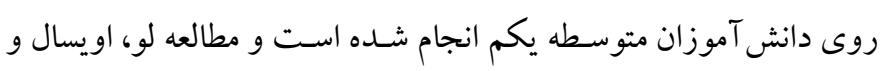
تئو (•r) در خروه دانشجويان انجام شده است. در تبيين اين نتيجه مى توان كفت كه بر اسـاس تئورى انتخاب بر ينج

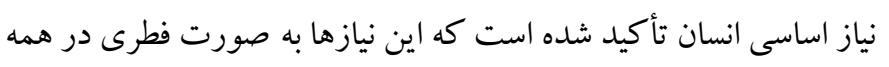

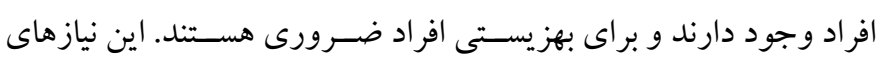


و زنـــى هـدفمنـدى را براى نوجوان فراهم آورد، بنـابر اين در نهايـت

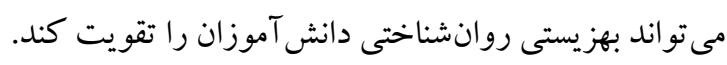

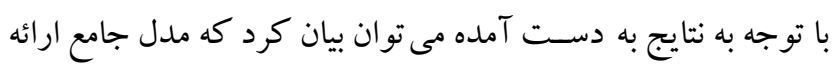

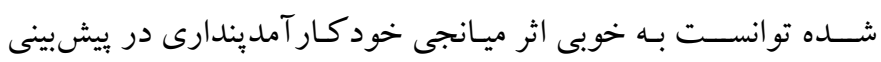

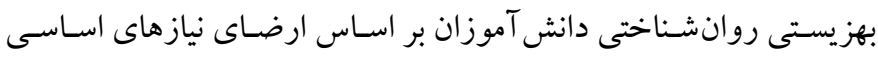

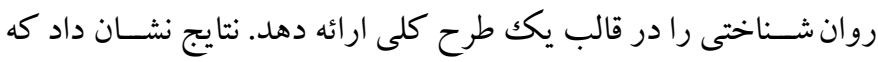

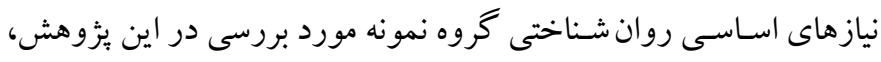

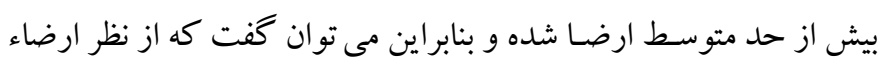
نيازهاى اسـاسى روان شـناختى درحد مطلوبى هستند. اين موضوع دربار ماره

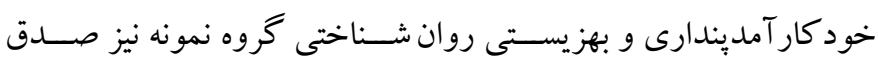

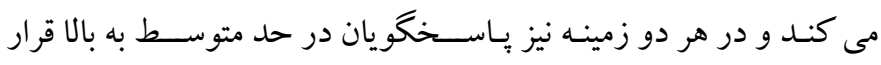

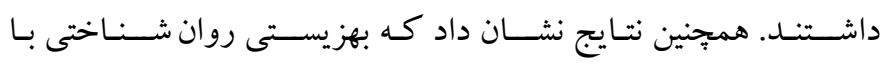

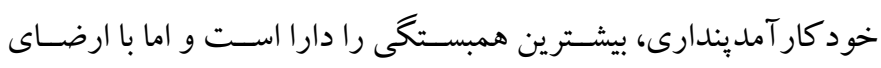

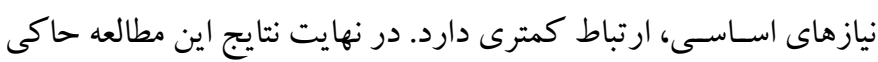

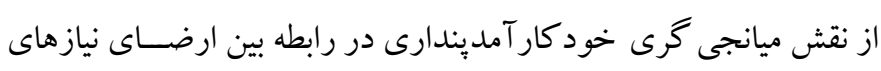

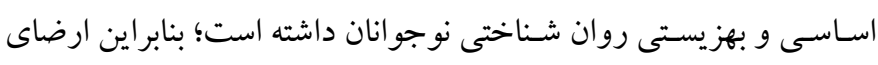

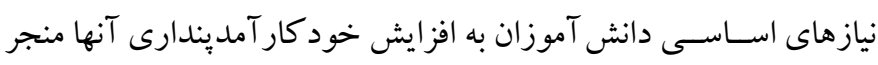

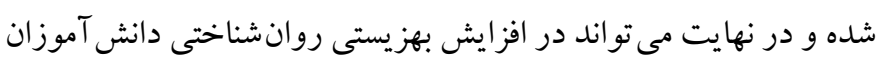

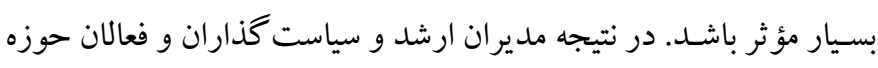

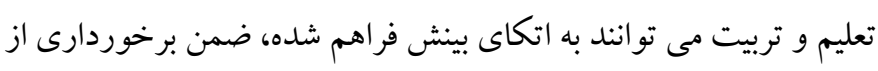

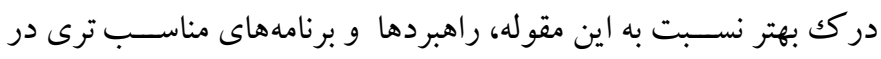

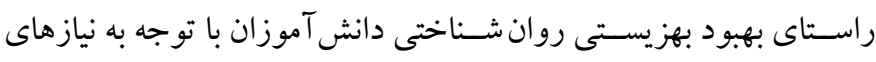
اساسى روانشناختى آنها با همر اهى والدين را طراحى كنئد.

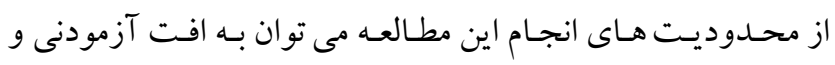

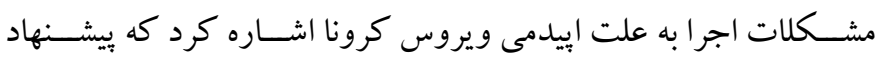

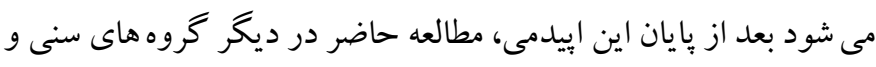

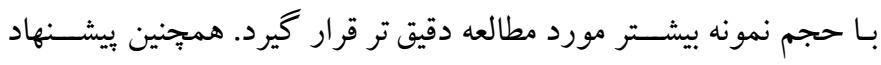

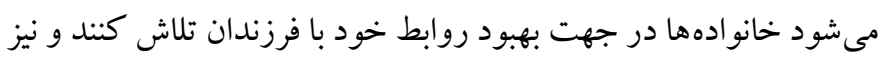

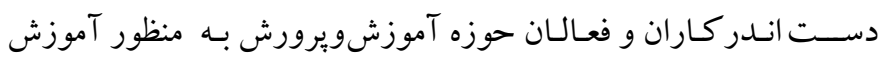

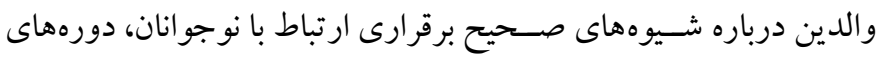

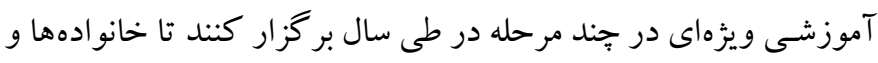

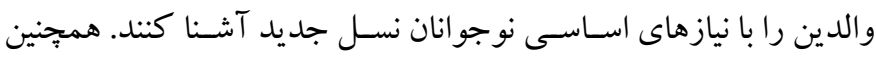

همان گونه كه در اين بثزوهش كفته شـد بهزيستى روان شناختى شامل

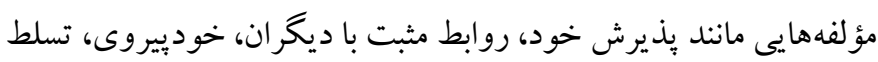

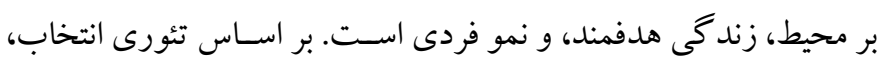

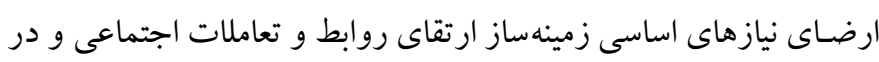

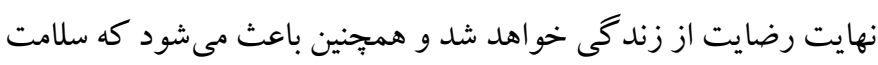

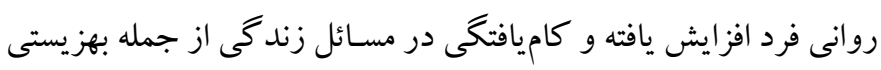

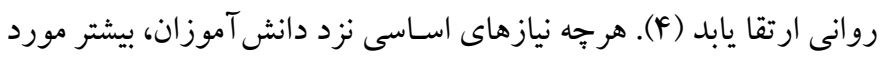

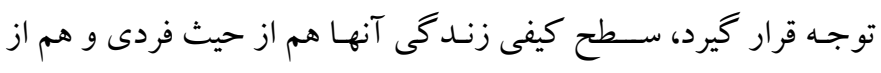

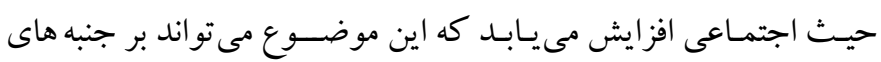

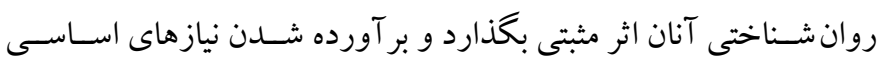

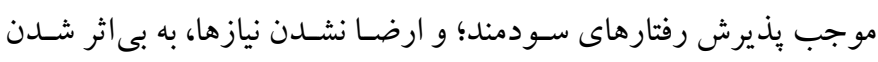
تلاشها در جهت بهسـازى و بيشرفت خود منجر مى شود. زمانى كه افراد رهاد

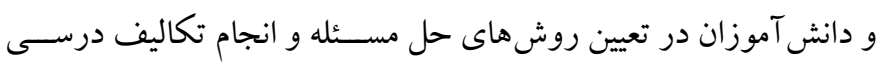

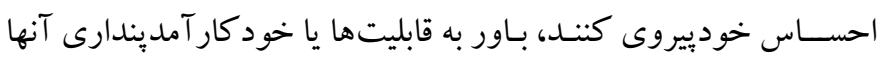

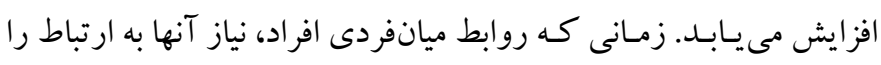

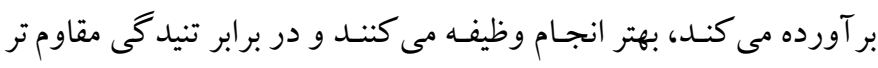

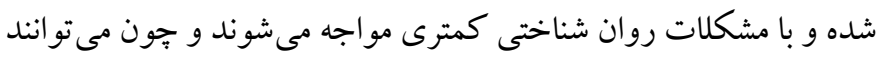

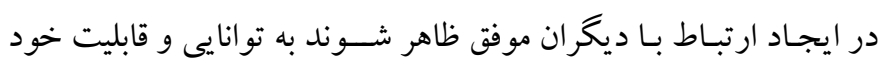
اعتمـاد و اطمينـان كرده و بـاورهـاى خود دكار آمديندارى آنها ارتقاء بِ بيدا مى كند.

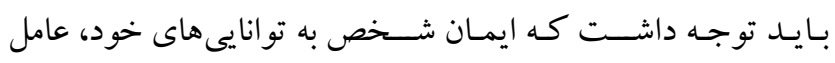

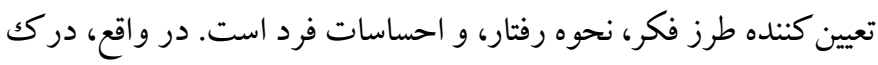

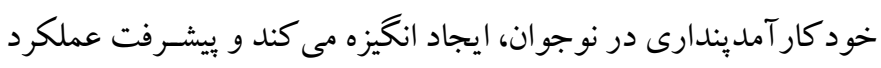

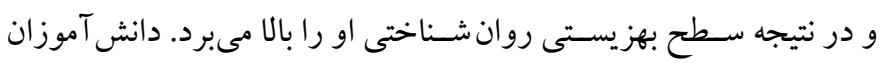

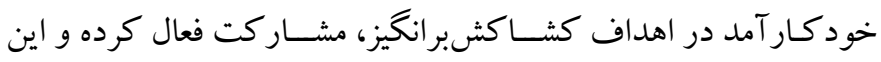

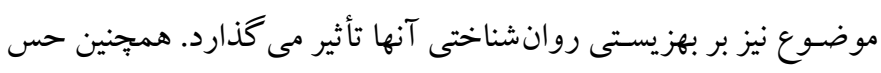

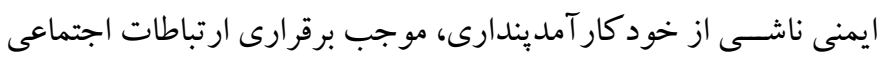

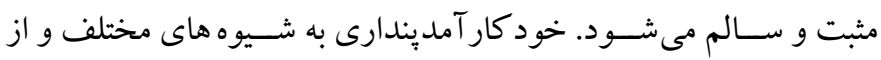

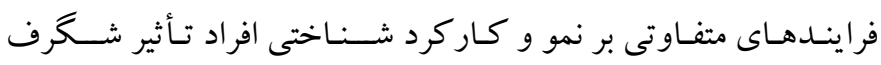

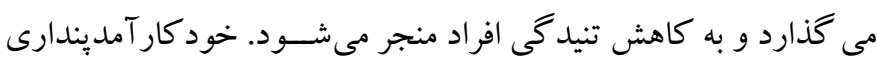

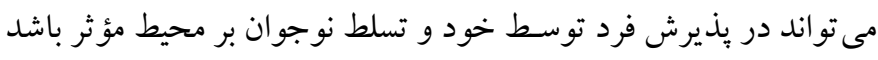


شـده اسـت. سـاير ملاحظات اخلاقى مانند رضـايت كامل افراد نمونه و رعايت اصـل رازدارى و محرمانه ماندن اطلاعات نيز در اين مطالعه در نظر گرفته شده است.

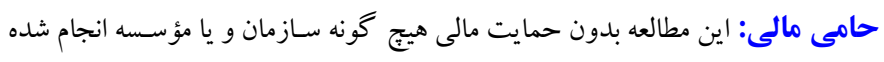
است.

نقش هر يكك از نويسـند كان: نو يســده نخسـت به عنوان طراح و ايدهيرداز اصسلى

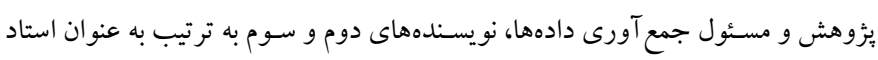

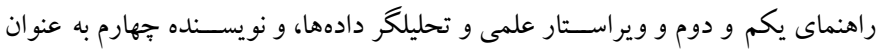
استاد مشاور در اين مقاله نقش داشتند. تضاد منافع: در اين مقاله تضاد منافع براى هيج كدام از نويسند گان وجود نداشته است.

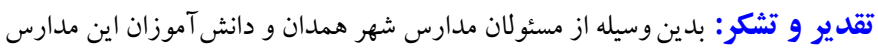
كه در اين يثزوهش شر كت داشتند، تشكر و قدردانى مىشود.
نقش مدارس در ايجاد فضـــاى مشــار كتى و برقرارى ارتباط مناســبـ با والـدين بـاعـث مى شــود تـا بتوانـــد بـه روشهــاى مختلف نوجوانـان را

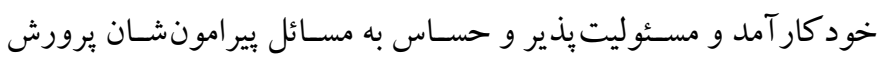
دهند.

\section{ملاحظات اخلاقى}

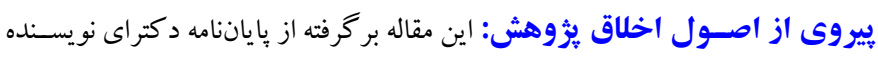

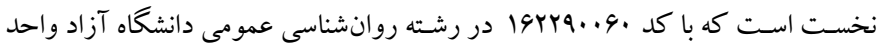

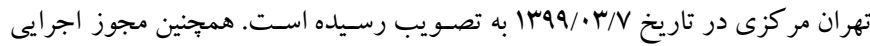

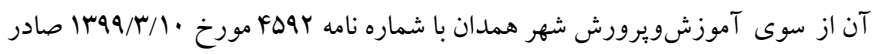




\section{References}

1. Beckmeyer JB, Weybright EH. Exploring the associations between middle adolescent romantic activity and positive youth development. Journal of Adolescence. 2020; 80(4): 214-219. [Link]

2. Entezari S, Taher M, Aghaei H. The Comparison of the Effectiveness of Cognitive Behavioral Therapy and Metacognitive Therapy on Depression, Suicide Ideation, and Masochistic Aggression in Individuals with Subclinical Symptoms of Body Dysmorphic Disorder. J Child Ment Health. 2021; 7(4): 1-18. [Persian] [Link]

3. Jin G, Wang Y. The influence of gratitude on learning engagement among adolescents: The multiple mediating effects of teachers' emotional support and students' basic psychological needs. Journal of Adolescence. Sommer 2019; 77: 21-31. [Link]

4. Taghvaeinia A. The Effectiveness of intervention based on positive education on the subjective wellbeing in students. Shenakht Journal of Psychology and Psychiatry. 2019; 6(1): 125-137. [Persian] [Link]

5. Chang, JH, Huang CL, Lin YC. Mindfulness, basic psychological needs fulfillment, and well-being. Journal of Happiness Studies. 2015; 16(5): 11491162. [Link]

6. Wilde N, Hsu A. The influence of general selfefficacy on the interpretation of vicarious experience information within online learning. International Journal of Educational Technology in Higher Education. 2019; 16(26): 2-20. [Persian] [Link]

7. Aghagedli P, Etemadi A. Studying the effectiveness of training Glasserl's Choice and control theory on identit $\mathrm{y}$ pattern evolution of adolescent. Journal of Psychological Studies. 2013; 8(4): 33-56. [Persian] [Link]

8. Witte K. Putting the fear back into fear appeals: The extended parallel process model. Communications Monographs. 1992; 59(4): 329-349. [Link]

9. Najd M, Mosahebi M, Atashpour H. Prediction of psychological well-being through components of selfefficacy, psychological hardiness \& perceived social support. Thoughts and Behavior in Clinical Psychology, 2014; 8(30): 47-56. [Persian] [Link]

10.Borg K, Barlow J. The behaviours and perceptions of paediatricians in Malta relating to child protection work: National and international implications of a mixed methods study. Child Abuse Review. 2018; 27(6): 446-467. [Link]

11. Akirmak U, Tuncer N, Akdogan M, Erkat OB. The associations of basic psychological needs and autonomous-related self with time perspective: The cultural and familial antecedents of balanced time perspective. Personality and Individual Differences, 2019; 139: 90-95. [Link]

12.Voci A, Veneziani CA. Fuochi G. Relating mindfulness, heartfulness, and psychological wellbeing: The role of self-compassion and grattude. Mindfulness. 2019; 10: 339-351. [Link]

13. Weich S, Brugha T, King M, McManus S, Bebbington $\mathrm{P}$, Jenkins R, StewartBrown S. Mental well-being aand mental illness: findings from the Adult Psychiatric Morbidity Survey for England 2007. The British Journal of Psychiatry, 2011; 199(1): 23-28. [Link]

14.Tatlilioğlu K. A Research of Relation between Undergraduates' Recognising Parent Attitudes with Psychological Well-being. Procedia - Social and Behavioral Sciences. August 2014; 143: 463-470. [Link]

15. Rousseau S, Deschacht N. Public awareness of nature and the environment during the COVID-19 crisis. Environmental and Resource Economics. 2020; 76 (1): 1149-1159. [Link]

16.Diener E, Oishi S, Lucas RE. Personality, culture, and subjective well-being: Emotional and Cognitive Evaluations of Life. Annual Review of Psychology. 2003; 54(1): 403-425. [Link]

17.Dargahi S, Mohsenzade F, Zahrakar K. The Effect of Positive Thinking Training on Psychological Wellbeing and Perceived Quality of Marital Relationship on Infertile Women. Positive Psychology Research. 2015; 1(3): 45-58. [Persian] [Link]

18. Hosein Abadi S, Pourshahryari M, Zandipour T. Effectiveness of positive psychology on psychological well-being of mothers of autistic children. Empowering Exceptional Children. 2017; 8(1): 54-60. [Persian] [Link]

19.Eghdami Z, Yousefi F. Relationship between basic psychological needs and academic engagement with mediating role of self-efficacy. Journal of Educational Psychology Studies; winter 2018; 15(29): 37-72. [Persian] [Link]

20.Lu Q, Uysal A, Teo I. emotionalambivalence, pain, and depressive symptomsNeed satisfaction and catastrophizing: Explaining therelationship among. Journalof Health Psychol. 2015; 16(5): 819-827. [Link]

21. Westland JC, Lower bounds on sample size in structural equation modeling. Electronic Commerce Research and Applications, 2010; 9(6): 476-487. [Link] 
22.Burns MK, Vance D, Seadokierski I, Stockwell C. Student Needs Survey: A Psychologically Sound Measure of the Five Basic Needs. International Journal of Reality Therapy. 2006; 2(7). [Link]

23.Haftlang F, Ebrahimi ME, Zamani N, Sahebi A. Investigating the relationship between the intensity of basic needs in Glasser's theory with marital satisfaction, mental health and mental well-being of married students. Cultural-educational women and family. 2019; 14 (47): 23-38. [Link]

24.Fathi A, Rezapour Y, Yaghouti Azar S. Determining the Relationship between Fundamental Needs and Social Support, and Social Consistency among Boy and Girl Student. Societal Security Studies. 2011; 2(25): 131-146. [Link]

25. Sherer M, Maddux JE, Mercandante B, Prentice-Dunn S, Jacobs B, Rogers RW. The Self-Efficacy Scale: Construction and Validation. Psychological Reports. 1982; 51(1): 663-71. [Link]

26.Tamadoni M, Hatami M, Hashemi Razini H. General self efficacy, academic procrastination and academic achievement in university students. Educational Psychology, 2010; 6(17): 66-88. [Persian] [Link]

27.Asgharnezhad T, Ahmadi Deh Ghotbedini M, Vali Allah F, Khoda Panahi MK, Study of psychometric properties of Sherer's general self-efficacy scale.
Journal of Psychology. Autumn 2006; 10(3): 262-274. [Persian] [Link]

28. Ryff CD, Keyes CLM. The structure of psychological well-being revisited. Journal of Personality and Social Psychology. 1995; 69(4): 719-727. [Link]

29. Ahmadian H, JomEhri F, Ahadi H, Farokhi N. Compilation and Testing the Model of the Relationship between Personality, Psychological Needs and Psychological Well-being. Journal of Psychological Achievements, 2011; 18(1): 1-18. [Persian] [Link]

30.Gravetter FJ, Wallnau LB. Statistics for the Behavioral Sciences. Edition 10, Cengage Learning; 2012. [Link]

31.George D, Mallery M. SPSS for Windows Step by Step: A Simple Guide and Reference, 17.0 update (10a ed.) Boston: Pearson; 2020. [Link]

32.Hooper D, Coughlan J, Mullen M. Structural Equation Modeling: Guidelines for Determining Model Fit. The Electronic Journal of Business Research Methods. 2007; 6 (1): 53-60. [Link]

33.Preacher KJ, Hayes AF. SPSS and SAS procedures for estimating indirect effects in simple mediation models. Behavior Research Methods, Instruments, Computers. 2004; 36 (1): 717-731. [Link] 